\title{
TRAM Linker: A Safety-Catch Linker for the Traceless Release of Acrylamides
}

\author{
Christopher J. Ciolli, ${ }^{1}$ Sean Kalagher, and Peter J. Belshaw ${ }^{1,2}$ \\ Departments of Chemistry ${ }^{I}$ and Biochemistry, ${ }^{2}$ University of Wisconsin, Madison, Wisconsin, \\ 53706.
}

Supporting Information 


\section{General Experimental Methods}

Sources. $\beta$-Alanine was purchased from Acros Organics (Geel, Belgium). EDCI was purchased from TCI America (Portland, OR). Aminomethyl Resin LS (0.6 mmol/g), Fmoc-Gly$\mathrm{OH}$ and Boc-Pro-OH were purchased from Advanced ChemTech (Louisville, KY). PyBOP and Z-Glu-OtBu:DCHA were purchased from Novabiochem (San Diego, CA). Silica-TBD (1,5,7triazabicyclo[4.4.0]dec-5-ene) was obtained as a generous gift from Silicycle (Quebec City, Quebec). All other reagents were purchased from Aldrich Chemical (Milwaukee, WI). Tetrahydrofuran (THF) was distilled from sodium/benzophenone ketyl. Dichloromethane (DCM) was distilled from phosphorous pentoxide. Diisopropylethylamine (DIEA) and triethylamine (TEA) were distilled from calcium hydride. $N, N$-Dimethylformamide (DMF) and methanol $(\mathrm{MeOH})$ were stored over AldraSORB. Chloroform- $d\left(\mathrm{CDCl}_{3}\right)$ was stored over potassium carbonate before use.

Reaction Methods. All moisture-sensitive reactions were performed in oven-dried glassware under a stream of nitrogen. Bath temperatures were used to record reaction temperatures in all cases. All solution-phase reactions were stirred magnetically. Solid-phase reactions were performed in $2 \mathrm{~mL}$ fritted polypropylene Bio-Spin ${ }^{\circledR}$ chromatography columns (Bio-Rad), $10 \mathrm{~mL}$ fritted polypropylene Poly-Prep ${ }^{\circledR}$ chromatography columns (Bio-Rad) or Teflon-capped glass vials. All solid-phase reactions were rotated $360^{\circ}$ on a BarnsteadThermolyne Labquake ${ }^{\circledR}$ shaker.

Purification and Analysis. Analytical thin-layer chromatography (TLC) was carried out on EM Science TLC plates precoated with silica gel $60 \mathrm{~F}_{254}(250 \mu \mathrm{m}$ layer thickness). TLC visualization was accomplished using either an UV lamp or charring solutions of either ninhydrin or phosphomolybdic acid (PMA). Flash column chromatography (FCC) was performed on Silicycle silica gel 60 (230-400 mesh). Optical rotations were obtained on a Perkin-Elmer 241 Polarimeter. Attenuated total reflectance (ATR) and thin film fourier transform infrared (FT-IR) spectra were obtained on a Bruker Tensor 27. Proton nuclear magnetic resonance $\left({ }^{1} \mathrm{H}\right.$ NMR) spectra were recorded at $300 \mathrm{MHz}$ using a Bruker $\mathrm{AC}+300$ spectrometer. Chemical shifts are expressed in ppm relative to TMS $(0.00 \mathrm{ppm})$ or residual solvent signal (DMSO- $\left.d_{6}, 2.50 \mathrm{ppm}\right)$. Carbon-13 nuclear magnetic resonance $\left({ }^{13} \mathrm{C}\right.$ NMR) spectra were recorded at $125 \mathrm{MHz}$ using either a Varian INOVA 500 or Varian UNITY 500 spectrometer, or at $75 \mathrm{MHz}$ using a Bruker $\mathrm{AC}+300 \mathrm{a}$. Chemical shifts are expressed in ppm 
relative to residual solvent signal $\left(\mathrm{CDCl}_{3} 77.0 \mathrm{ppm}\right.$, DMSO- $\left.d_{6} 39.5 \mathrm{ppm}\right)$. High-resolution electrospray ionization mass spectra (HRESI-MS) were obtained on a Micromass LCT.

\section{Synthesis of TRAM Linker}
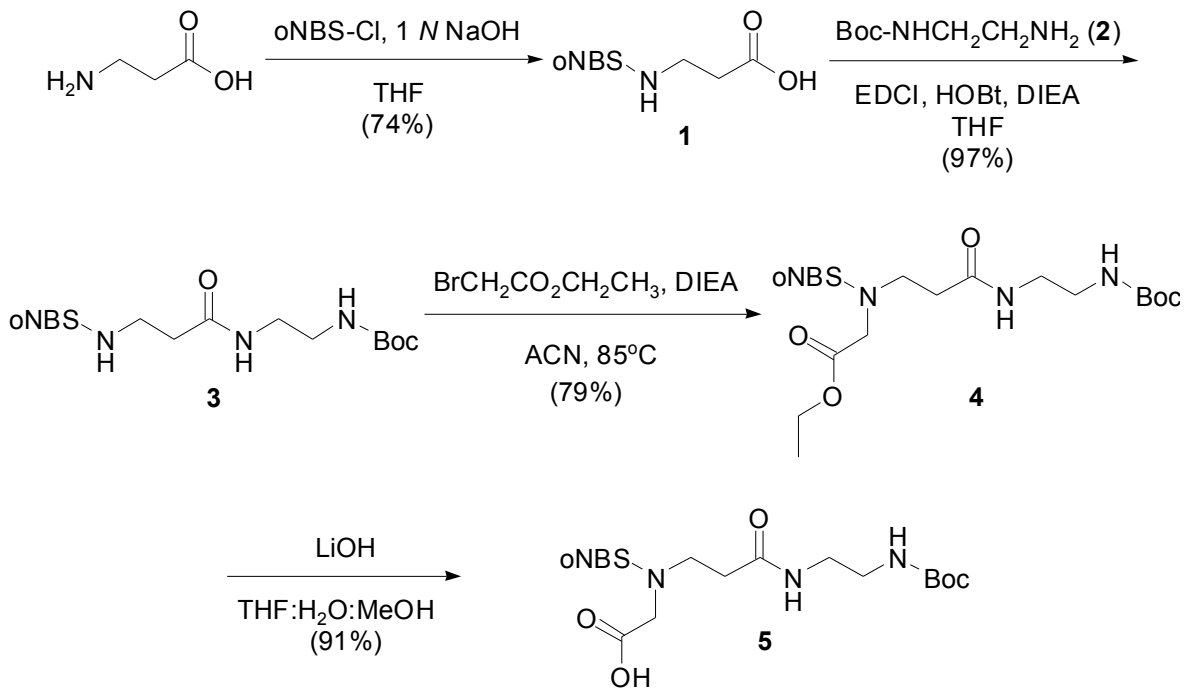

Compound 1 was previously reported; ${ }^{1}$ however, a complete characterization was not included. Compound $\mathbf{2}$ was prepared as previously reported. ${ }^{2}$ Alternatively, compound $\mathbf{2}$ is also commercially available from Aldrich Chemical (Milwaukee, WI).

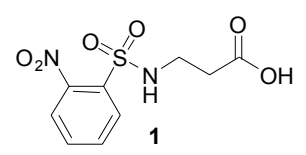

$\boldsymbol{N}$-[(o-nitrophenyl)sulfonyl]- $\beta$-Alanine (1). To a $0^{\circ} \mathrm{C}$ solution of $\beta$-alanine $(3.00 \mathrm{~g}, 33.7 \mathrm{mmol})$ in $1 \mathrm{~N} \mathrm{NaOH}(40 \mathrm{~mL})$ and THF $(35 \mathrm{~mL})$ was added a solution of 2-nitrobenzenesulfonyl chloride $(8.95 \mathrm{~g}, 40.4 \mathrm{mmol})$ in $1 \mathrm{~N} \mathrm{NaOH}(47 \mathrm{~mL})$ in five portions over $1 \mathrm{~h}$. After an additional $30 \mathrm{~min}$ at $0^{\circ} \mathrm{C}$, the THF was evaporated. The remaining aqueous solution was washed with ether $(2 \times 30$ $\mathrm{mL}$ ), then adjusted to $\mathrm{pH}=1$ via addition of concentrated $\mathrm{HCl}$. The yellow precipitate was collected by vacuum filtration and recrystallized from water to give $6.80 \mathrm{~g} \mathrm{(74 \% )}$ of 1 as white crystalline needles. $\mathrm{R}_{f}=0.65$ (95\% ethanol in water); FT-IR (ATR) 3371, 1697, 1538, 1425, 1361, 1338, 1233, 1162, 1093, 857, 779, $744 \mathrm{~cm}^{-1} ;{ }^{1} \mathrm{H}$ NMR (Acetone- $\left.d_{6}, 300 \mathrm{MHz}\right) \delta 10.83(\mathrm{~s}$ (broad), 1H), 8.17 (m, 1H), 7.95 (m, 3H), 6.70 (s (broad), 1H), 3.38 (dt, $J=6.3,5.7 \mathrm{~Hz}, 2 \mathrm{H}) 2.62$ $(\mathrm{t}, J=6.8 \mathrm{~Hz}, 2 \mathrm{H}) ;{ }^{13} \mathrm{C}$ NMR (Acetone- $\left.d_{6}, 75 \mathrm{MHz}\right) \delta 173.28,149.60,135.40,134.61,134.09$, 131.83, 126.31, 40.58, 34.85; MS (HRESI-MS) calculated for $\left[\mathrm{C}_{9} \mathrm{H}_{10} \mathrm{~N}_{2} \mathrm{O}_{6} \mathrm{~S}-\mathrm{H}\right]^{-} 273.0181$, found 273.0190 . 


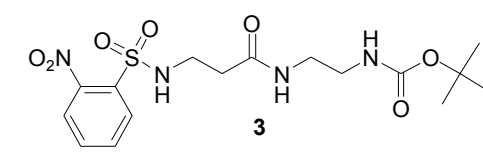

oNBS- $\beta$-Alanine- $N$-Boc-ethylenediamine amide 3. To a solution of 1 (2.20 g, $8.02 \mathrm{mmol})$ and DIEA $(1.4 \mathrm{~mL}, 8.0 \mathrm{mmol})$ in THF $(10 \mathrm{~mL})$ was added a solution of $2(1.28 \mathrm{~g}, 7.99 \mathrm{mmol})$ in THF (10 mL). HOBt (0.54 g, $4.0 \mathrm{mmol})$ and additional DIEA (1.4 mL, $8.0 \mathrm{mmol})$ were added. Lastly, EDCI (1.84 g, $9.60 \mathrm{mmol})$ was added. After $4 \mathrm{~h}$, the solvent was evaporated and the crude oil was dissolved in EtOAc $(100 \mathrm{~mL})$. The organic solution was washed with $1 \mathrm{~N} \mathrm{HCl}(2$ $\times 50 \mathrm{~mL})$, water $(50 \mathrm{~mL})$, saturated $\mathrm{NaHCO}_{3}(2 \times 50 \mathrm{~mL})$, water $(50 \mathrm{~mL})$, brine $(50 \mathrm{~mL})$ and then dried $\left(\mathrm{Na}_{2} \mathrm{SO}_{4}\right)$, filtered and evaporated to give $3.22 \mathrm{~g}(97 \%)$ of 3 as a yellow foam. $\mathrm{R}_{f}=$ 0.50 (10\% MeOH in DCM); FT-IR (ATR) 3325, 1692, 1655, 1540, 1365, 1340, 1251, 1164, 1126, 854, 783, $741 \mathrm{~cm}^{-1} ;{ }^{1} \mathrm{H} \mathrm{NMR}\left(\mathrm{CDCl}_{3}, 300 \mathrm{MHz}\right) \delta 8.13(\mathrm{~m}, 1 \mathrm{H}), 7.86(\mathrm{~m}, 1 \mathrm{H}), 7.74(\mathrm{~m}$, 2H), 6.47 (s (broad), 1H), 6.33 (t, $J=6.0 \mathrm{~Hz}, 1 \mathrm{H}), 4.99$ (t, $J=5.5 \mathrm{~Hz}, 1 \mathrm{H}), 3.35$ (m, 4H), 3.24 $(\mathrm{m}, 2 \mathrm{H}), 2.48(\mathrm{t}, J=6.0 \mathrm{~Hz}, 2 \mathrm{H}), 1.43(\mathrm{~s}, 9 \mathrm{H}) ;{ }^{13} \mathrm{C} \mathrm{NMR}\left(\mathrm{CDCl}_{3}, 75 \mathrm{MHz}\right) \delta 171.44,157.11$, $148.21,133.78,133.64,132.93,131.01,125.47,79.84,40.80,40.25,40.10,35.58,28.50$ (3C); MS (HRESI-MS) calculated for $\left[\mathrm{C}_{16} \mathrm{H}_{24} \mathrm{~N}_{4} \mathrm{O}_{7} \mathrm{~S}+\mathrm{Na}\right]^{+} 439.1263$, found 439.1246 .

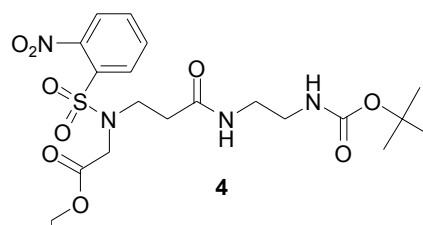

Protected linker 4. To a solution of 3 (8.2618 g, $19.839 \mathrm{mmol})$ in minimal acetonitrile (11.0 $\mathrm{mL})$ was added DIEA $(10.4 \mathrm{~mL}, 59.7 \mathrm{mmol})$ and ethyl bromoacetate $(6.6 \mathrm{~mL}, 60 \mathrm{mmol})$. The solution was then heated to reflux. After $17 \mathrm{~h}$ at reflux, the reaction was allowed to cool to room temperature and the solvent was evaporated. The orange oily residue was taken up in EtOAc $(400 \mathrm{~mL})$, which was then washed with $1 \mathrm{~N} \mathrm{HCl}(4 \times 200 \mathrm{~mL})$ and brine $(200 \mathrm{~mL})$, dried $\left(\mathrm{Na}_{2} \mathrm{SO}_{4}\right)$, filtered and evaporated. The crude orange oil was triturated with ether, and the product was collected by vacuum filtration then washed with ice-cold ether. Removal of residual ether in vacuo gave $7.8561 \mathrm{~g}(79 \%)$ of 4 as a white powder. $\mathrm{R}_{f}=0.60(10 \% \mathrm{MeOH}$ in DCM); FT-IR (ATR) 3332, 1738, 1681, 1643, 1545, 1373, 1215, 1163, $773 \mathrm{~cm}^{-1} ;{ }^{1} \mathrm{H} \mathrm{NMR}\left(\mathrm{CDCl}_{3}, 300\right.$ MHz) $\delta 8.08$ (m, 1H), $7.71(\mathrm{~m}, 2 \mathrm{H}), 7.62$ (m, 1H), 6.61 (s (broad), 1H), 5.16 (s (broad), 1H), $4.24(\mathrm{~s}, 2 \mathrm{H}), 4.10(\mathrm{q}, J=7.2 \mathrm{~Hz}, 2 \mathrm{H}), 3.68(\mathrm{t}, J=6.3 \mathrm{~Hz}, 2 \mathrm{H}), 3.36(\mathrm{~m}, 2 \mathrm{H}), 3.26(\mathrm{~m}, 2 \mathrm{H}), 2.58$ $(\mathrm{t}, J=6.5 \mathrm{~Hz}, 2 \mathrm{H}), 1.44(\mathrm{~s}, 9 \mathrm{H}), 1.21(\mathrm{t}, J=7.2 \mathrm{~Hz}, 3 \mathrm{H}) ;{ }^{13} \mathrm{C} \mathrm{NMR}\left(\mathrm{CDCl}_{3}, 75 \mathrm{MHz}\right) \delta 171.12$, 
$169.42,156.81,148.21,133.94,132.76,131.96,131.15,124.30,79.72,61.72,50.25,46.07$, 40.60, 40.50, 36.42, 28.54 (3C), 14.19; MS (HRESI-MS) calculated for $\left[\mathrm{C}_{20} \mathrm{H}_{30} \mathrm{~N}_{4} \mathrm{O} 9 \mathrm{~S}+\mathrm{H}\right]^{+}$ 503.1812, found 503.1826.

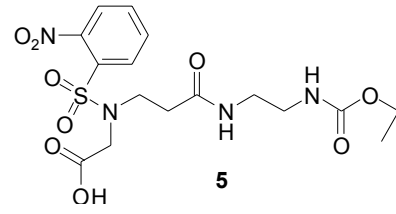

Linker carboxylic acid 5. To a solution of 4 (1.6480 g, $3.2793 \mathrm{mmol})$ in THF: $\mathrm{H}_{2} \mathrm{O}: \mathrm{MeOH}$ $(3: 2: 1,18 \mathrm{~mL})$ was added lithium hydroxide $(240.9 \mathrm{mg}, 10.06 \mathrm{mmol})$. After $2 \mathrm{~h}$, the reaction was poured into $3 \mathrm{M} \mathrm{HCl}(15 \mathrm{~mL})$. The aqueous layer was extracted with EtOAc $(4 \times 40 \mathrm{~mL})$. The combined organic extracts were washed with $0.1 \mathrm{M} \mathrm{HCl}(3 \times 60 \mathrm{~mL})$ and brine $(60 \mathrm{~mL})$, and then dried $\left(\mathrm{Na}_{2} \mathrm{SO}_{4}\right)$, filtered and evaporated to give $1.423 \mathrm{~g}(91 \%)$ of 5 as a white powder. $\mathrm{R}_{f}=$ 0.12 (10\% MeOH in $\mathrm{CHCl}_{3}$ ); FT-IR (ATR) 3436, 3266, 1730, 1696, 1605, 1550, 1218, 1164 $\mathrm{cm}^{-1} ;{ }^{1} \mathrm{H}$ NMR (DMSO- $\left.d_{6}, 300 \mathrm{MHz}\right) \delta 12.96$ (s (broad), 1H), 8.09 (m, 1H), 7.96 (m, 2H), 7.86 $(\mathrm{m}, 2 \mathrm{H}), 6.78(\mathrm{t}, J=5.5 \mathrm{~Hz}, 1 \mathrm{H}), 4.13(\mathrm{~s}, 2 \mathrm{H}), 3.54(\mathrm{t}, J=7.1 \mathrm{~Hz}, 2 \mathrm{H}), 3.01(\mathrm{t}, J=5.4 \mathrm{~Hz}, 2 \mathrm{H})$, $2.96(\mathrm{t}, J=5.4 \mathrm{~Hz}, 2 \mathrm{H}), 2.41(\mathrm{t}, J=7.1 \mathrm{~Hz}, 2 \mathrm{H}), 1.37(\mathrm{~s}, 9 \mathrm{H}) ;{ }^{13} \mathrm{C}$ NMR (DMSO- $\left.d_{6}, 125 \mathrm{MHz}\right) \delta$ $170.05,169.82$, 155.58, 147.46, 134.40, 132.39, 131.87, 130.02, 124.15, 77.66, 48.59, 45.05, 39.34, 38.70, 34.57, 28.21 (3C); MS (HRESI-MS) calculated for $\left[\mathrm{C}_{18} \mathrm{H}_{26} \mathrm{~N}_{4} \mathrm{O}_{9} \mathrm{~S}-\mathrm{H}\right]^{-} 473.1343$, found 473.1339 .

\section{Synthesis of Model Derivative}

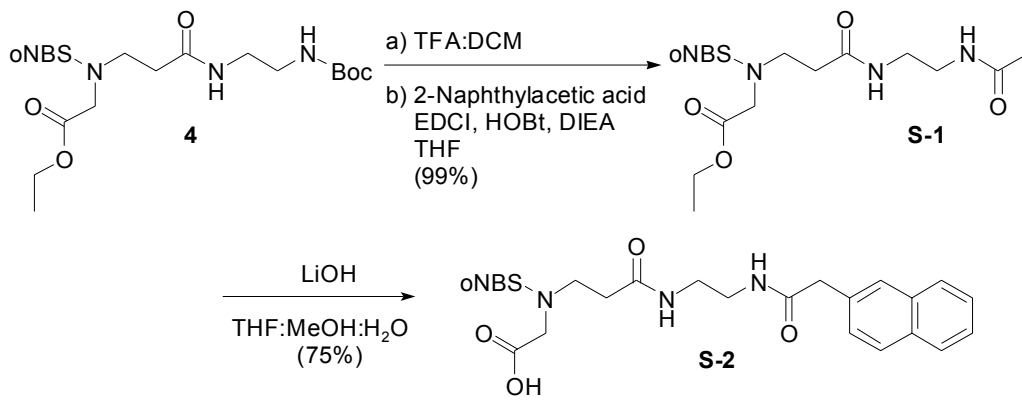




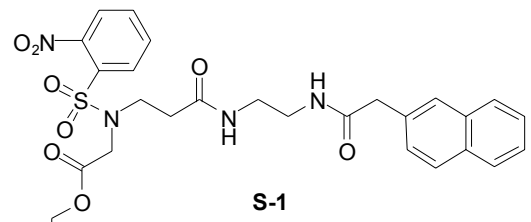

Naphthyl linker S-1. To a solution of $4(256.5 \mathrm{mg}, 0.5098 \mathrm{mmol})$ in DCM (1.5 mL) was added TFA $(320 \mu \mathrm{L})$. After $3.5 \mathrm{~h}$, the solvent was evaporated. The yellow oily residue was evaporated from ether $(5 \times 5 \mathrm{~mL})$, then concentrated in vacuo. The crude free primary amine was dissolved in THF (4.2 mL) and neutralized with DIEA $(135 \mu \mathrm{L}, 0.775 \mathrm{mmol})$. To this solution was added 2-naphthyl acetic acid (114.1 mg, $0.6127 \mathrm{mmol})$, HOBt (82.8 mg, $0.613 \mathrm{mmol})$, then EDCI (118.7 mg, $0.6192 \mathrm{mmol})$. Lastly, additional DIEA (135 $\mu \mathrm{L}, 0.775 \mathrm{mmol})$ was added. After 22 $\mathrm{h}$, the solvent was evaporated, and the crude orange residue was taken up in EtOAc $(50 \mathrm{~mL})$. The organic solution was washed with $1 \mathrm{~N} \mathrm{HCl}(3 \times 25 \mathrm{~mL})$, water $(25 \mathrm{~mL})$, sat. $\mathrm{NaHCO}_{3}(3 \times$ $25 \mathrm{~mL})$, water $(25 \mathrm{~mL})$ and brine $(25 \mathrm{~mL})$, dried $\left(\mathrm{Na}_{2} \mathrm{SO}_{4}\right)$, filtered and evaporated to give 290.0 mg (99\%) of S-1 as a white powder. $\mathrm{R}_{f}=0.53(10 \% \mathrm{MeOH}$ in DCM); FT-IR (ATR) 3295, 1742, 1640, 1545, 1374, 1208, 1164, 947, 854, 776, $741 \mathrm{~cm}^{-1} ;{ }^{1} \mathrm{H} \mathrm{NMR}\left(\mathrm{CDCl}_{3}, 300 \mathrm{MHz}\right) \delta 8.00(\mathrm{~m}$, 1H), 7.80 (m, 3H), 7.73-7.59 (m, 4H), 7.49-7.38 (m, 3H), 6.57 (s (broad), 1H), 6.32 (s (broad), 1H), 4.16 (s, 2H), 4.07 (q, $J=7.6 \mathrm{~Hz}, 2 \mathrm{H}), 3.71(\mathrm{~s}, 2 \mathrm{H}), 3.59$ (t, $J=6.3 \mathrm{~Hz}, 2 \mathrm{H}), 3.33(\mathrm{~m}, 4 \mathrm{H})$, $2.44(\mathrm{t}, J=6.3 \mathrm{~Hz}, 2 \mathrm{H}), 1.19(\mathrm{t}, J=7.2 \mathrm{~Hz}, 3 \mathrm{H}) ;{ }^{13} \mathrm{C}$ NMR (DMSO-d, $\left.75 \mathrm{MHz}\right) \delta 170.21$, 169.86, 168.58, 147.40, 134.52, 133.97. 132.98, 132.41, 131.76, 131.65, 130.07, 127.63, 127.56, 127.42 , 127.36, 127.29, 126.02, 125.47, 124.19, 60.80, 48.74, 45.11, 42.53, 38.41, 38.33, 34.70, 13.82; MS (HRESI-MS) calculated for $\left[\mathrm{C}_{27} \mathrm{H}_{30} \mathrm{~N}_{4} \mathrm{O}_{8} \mathrm{~S}+\mathrm{Na}\right]^{+}$593.1682, found 593.1707.

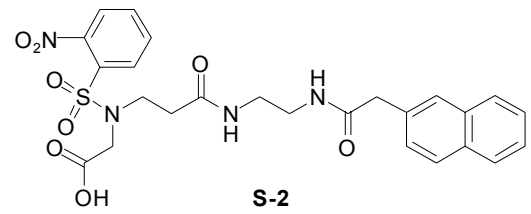

Model compound S-2. To a $0{ }^{\circ} \mathrm{C}$ solution of S-1 (275.0 mg, $\left.0.4819 \mathrm{mmol}\right)$ in THF: $\mathrm{H}_{2} \mathrm{O}: \mathrm{MeOH}$ (3:2:1, $18 \mathrm{~mL})$ was added lithium hydroxide $(23.5 \mathrm{mg}, 0.981 \mathrm{mmol})$. After $1 \mathrm{~h}$, the reaction was poured into $3 \mathrm{M} \mathrm{HCl}(9 \mathrm{~mL})$. The aqueous layer was extracted with EtOAc $(3 \times 30 \mathrm{~mL})$. The combined organic extracts were dried $\left(\mathrm{Na}_{2} \mathrm{SO}_{4}\right)$, filtered and evaporated. The crude yellow oil was triturated with EtOAc, and then the product was collected by vacuum filtration, washed with $\mathrm{Et}_{2} \mathrm{O}$ and dried in vacuo to give $195.0 \mathrm{mg}(75 \%)$ of $\mathbf{S}-2$ as a white powder. $\mathrm{R}_{f}=0.13(10 \%$ $\mathrm{MeOH}$ in DCM + 1\% AcOH); FT-IR (ATR) 3294, 1739, 1648, 1596, 1544, 1376, 1359, 1205, 
$1161,1128,946,854,819,770,732 \mathrm{~cm}^{-1}$; ${ }^{1} \mathrm{H}$ NMR (DMSO- $\left.d_{6}, 300 \mathrm{MHz}\right) \delta 12.92$ (s (broad), $1 \mathrm{H}), 8.10(\mathrm{~m}, 2 \mathrm{H}), 8.02(\mathrm{~s}$ (broad), 1H), $7.95(\mathrm{~m}, 1 \mathrm{H}), 7.89-7.79(\mathrm{~m}, 5 \mathrm{H}), 7.74(\mathrm{~s}, 1 \mathrm{H}), 7.52-7.40$ (m, 3H), 4.13 (s, 2H), $3.54(\mathrm{~m}, 4 \mathrm{H}), 3.09(\mathrm{~m}, 4 \mathrm{H}), 2.41$ (t, $J=7.2 \mathrm{~Hz}, 2 \mathrm{H}) ;{ }^{13} \mathrm{C}$ NMR (DMSO- $d_{6}$, $75 \mathrm{MHz}) \delta 170.19,169.99,169.86,147.45,134.40,133.97,132.96,132.36,131.82,131.75$, $130.00,127.62$, 127.55, 127.43, 127.35, 127.27, 126.01, 125.46, 124.13, 48.57, 45.04, 42.51, 38.40, 38.31, 34.59; MS (HRESI-MS) calculated for $\left[\mathrm{C}_{25} \mathrm{H}_{26} \mathrm{~N}_{4} \mathrm{O}_{8} \mathrm{~S}-\mathrm{H}\right]^{-} 541.1393$, found 541.1387.

\section{Optimization of Linker Chemistry}
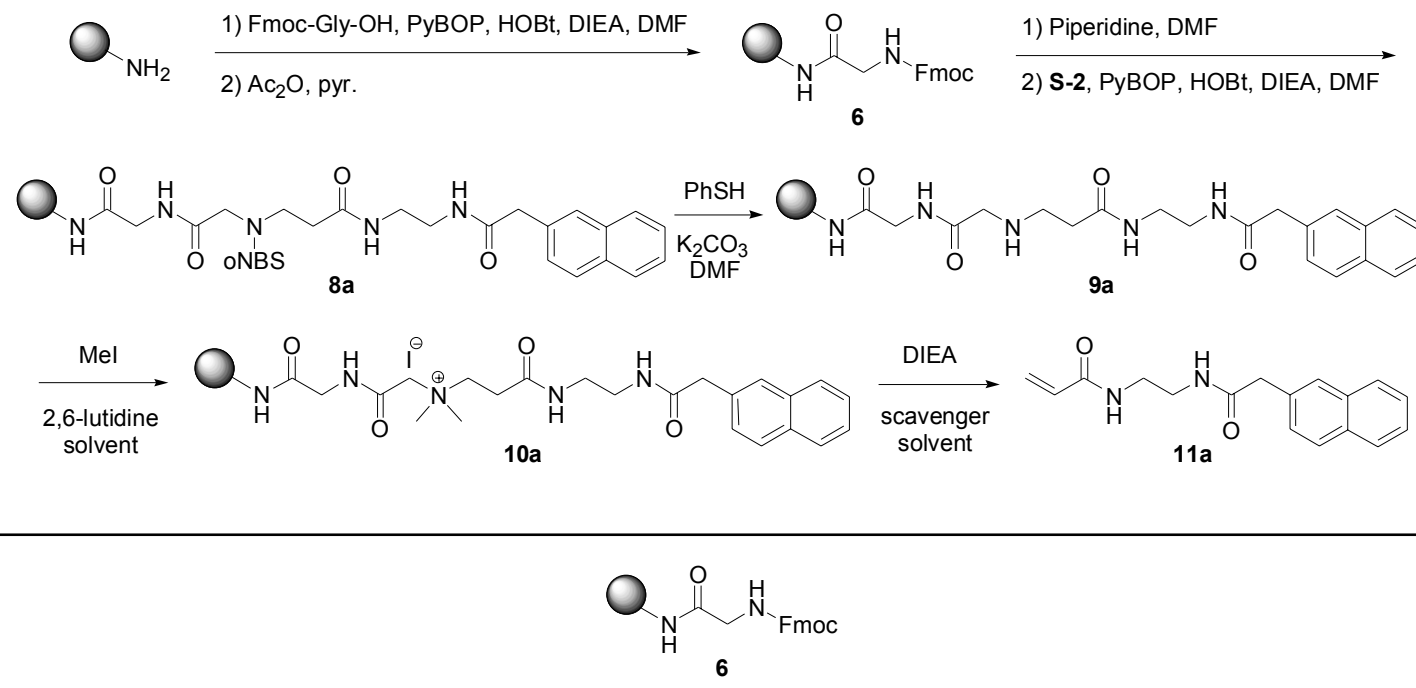

Resin 6. To a solution of Fmoc-Gly-OH (176.4 mg, $0.5933 \mathrm{mmol})$ in DMF $(0.36 \mathrm{~mL})$ was added PyBOP (339.6 mg, $0.6527 \mathrm{mmol})$ in DMF (0.94 mL), HOBt (80.2 mg, $0.594 \mathrm{mmol})$ in DMF $(0.21 \mathrm{~mL})$ and then DIEA $(155 \mu \mathrm{L}, 0.890 \mathrm{mmol})$. This solution was added to aminomethyl resin LS (498.2 mg, $0.3 \mathrm{mmol})$ pre-swollen in DMF $(2.5 \mathrm{~mL})$. After $3 \mathrm{~h}$, pyridine $(74 \mu \mathrm{L}, 0.91$ mmol) and acetic anhydride $(86 \mu \mathrm{L}, 0.91 \mathrm{mmol})$ were added to cap any unreacted amines. After $1.5 \mathrm{~h}$ of capping, the resin was washed with DMF $(3 \times 3 \mathrm{~mL}), \mathrm{DCM}(3 \times 3 \mathrm{~mL}), \mathrm{DMF}(3 \times 3$ $\mathrm{mL})$, $\mathrm{DCM}(3 \times 3 \mathrm{~mL}), \mathrm{MeOH}(3 \times 3 \mathrm{~mL})$ and ether $(3 \times 3 \mathrm{~mL})$. The resin was dried in vacuo overnight and then subjected to Fmoc analysis ${ }^{3}$ to determine an experimental loading level of $0.52 \mathrm{mmol} / \mathrm{g}$. 


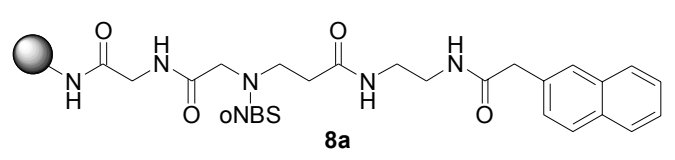

Resin 8a. Resin 6 (561.8 mg, $0.29 \mathrm{mmol}$ ) was treated with 20\% piperidine in DMF for $30 \mathrm{~min}$ $(2 \times 5 \mathrm{~mL})$, then washed with DMF $(3 \times 3 \mathrm{~mL}), \mathrm{DCM}(3 \times 3 \mathrm{~mL}), \mathrm{DMF}(3 \times 3 \mathrm{~mL}), \mathrm{DCM}(3 \times$ $3 \mathrm{~mL}), \mathrm{MeOH}(3 \times 3 \mathrm{~mL})$ and ether $(3 \times 3 \mathrm{~mL})$, and then dried. To a solution of $\mathbf{S - 2}(318.6 \mathrm{mg}$, $0.5872 \mathrm{mmol})$ in DMF (0.64 mL) was added PyBOP (336.8 mg, $0.6473 \mathrm{mmol})$ in DMF (0.85 $\mathrm{mL})$, HOBt $(79.7 \mathrm{mg}, 0.590 \mathrm{mmol})$ in DMF $(0.18 \mathrm{~mL})$ and then DIEA (154 $\mu \mathrm{L}, 0.884 \mathrm{mmol})$. This solution was added to deprotected resin 6 pre-swollen in DMF $(2.5 \mathrm{~mL})$. After $17 \mathrm{~h}$, the Kaiser test indicated complete acylation of amines on resin. The resin was washed with DMF (3 $\times 3 \mathrm{~mL}), \mathrm{DCM}(3 \times 3 \mathrm{~mL}), \mathrm{DMF}(3 \times 3 \mathrm{~mL}), \mathrm{DCM}(3 \times 3 \mathrm{~mL}), \mathrm{MeOH}(3 \times 3 \mathrm{~mL})$ and ether $(3$ $\times 3 \mathrm{~mL}$ ), and then dried in vacuo.

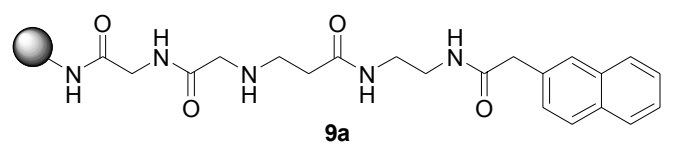

Resin 9a. The oNBS deprotection reagent was prepared as follows: To a suspension of $\mathrm{K}_{2} \mathrm{CO}_{3}$ (2.7072 g, $19.588 \mathrm{mmol})$ in DMF (19 mL) was added benzenethiol (1.0 mL, $9.7 \mathrm{mmol})$ (CAUTION: STENCH). Resin 8a $(649.2 \mathrm{mg}, 0.29 \mathrm{mmol})$ was treated with the oNBS deprotection reagent for $10 \mathrm{~min}(3 \times 5 \mathrm{~mL})$. A bright yellow solution was indicative of oNBS deprotection. The resin was washed with DMF $(3 \times 3 \mathrm{~mL}), \mathrm{DCM}(3 \times 3 \mathrm{~mL}), \mathrm{DMF}(3 \times 3 \mathrm{~mL})$, DCM $(3 \times 3 \mathrm{~mL}), 5 \%$ DIEA in DCM $(3 \times 3 \mathrm{~mL}), \mathrm{DCM}(3 \times 3 \mathrm{~mL}), \mathrm{MeOH}(3 \times 3 \mathrm{~mL})$ and ether $(3 \times 3 \mathrm{~mL})$, and then dried in vacuo.

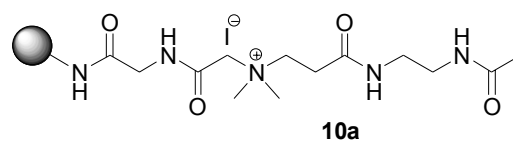

Resin 10a. To resin 9a $(40.7 \mathrm{mg}, 0.020 \mathrm{mmol})$, pre-swollen in DMSO (0.4 mL), was added 2,6lutidine $(87 \mu \mathrm{L}, 0.80 \mathrm{mmol})$ and iodomethane $(50 \mu \mathrm{L}, 0.80 \mathrm{mmol})$. After $3 \mathrm{~h}$, resin was washed with DMF $(3 \times 1 \mathrm{~mL}), \operatorname{DCM}(3 \times 1 \mathrm{~mL}), \operatorname{DMF}(3 \times 1 \mathrm{~mL}), \mathrm{DCM}(3 \times 1 \mathrm{~mL}), \mathrm{MeOH}(3 \times 1 \mathrm{~mL})$ and ether $(3 \times 1 \mathrm{~mL})$, and then dried in vacuo.

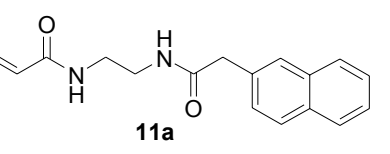

Acrylamide 11a. To a suspension of resin 10a (37.9 mg, $0.017 \mathrm{mmol})$ and PS-TBD (70.0 mg, $0.18 \mathrm{mmol})$ in DMF $(1.0 \mathrm{~mL})$ was added DIEA $(6.1 \mu \mathrm{L}, 0.035 \mathrm{mmol})$. After $17 \mathrm{~h}$, the resin was 
washed with DMF $(3 \times 0.5 \mathrm{~mL})$, and the cleavage solution and combined resin washes were evaporated to give $2.9 \mathrm{mg}(59 \%)$ of $11 \mathrm{a}$ as a white solid (identical to compound 11a prepared via the alternative solid-phase route and solution-phase route (vide infra)).

General procedure for evaluation of equivalents Hunig's base and solvent used in cleavage reaction. Resin 10a (19.3 $\mathrm{mg}, 0.0089 \mathrm{mmol})$ and silica-TBD (94.4 mg, $0.089 \mathrm{mmol})$ were suspended in solvent $(500 \mu \mathrm{L})$. DIEA was added. After $16 \mathrm{~h}$, resin was washed with DMF $(3 \times$ $0.5 \mathrm{~mL}$ ). Combined cleavage solution and washes were brought to $2.0 \mathrm{~mL}$ final volume in a volumetric flask.

\section{General procedure for evaluation of solid-supported acid scavengers used in cleavage} reaction. Resin 10a (19.3 mg, $0.0089 \mathrm{mmol})$ and acid scavenger were suspended in DMF (500 $\mu L)$. DIEA $(3.1 \mu \mathrm{L}, 0.018 \mathrm{mmol})$ was added. After $16 \mathrm{~h}$, resin was washed with DMF $(3 \times 0.5$ $\mathrm{mL}$ ). Combined cleavage solution and washes were brought to $2.0 \mathrm{~mL}$ final volume in a volumetric flask.

General procedure for evaluation of equivalents methyl iodide/2,6-lutidine and solvent used in the quaternization reaction. Resin 9a (20.4 mg, $0.010 \mathrm{mmol})$ was suspended in solvent (200 $\mu \mathrm{L})$. 2,6-Lutidine and then methyl iodide were added. After $16 \mathrm{~h}$, resin was washed with DMF $(3 \times 0.5 \mathrm{~mL}), \mathrm{DCM}(3 \times 0.5 \mathrm{~mL}), \mathrm{DMF}(3 \times 0.5 \mathrm{~mL}), \mathrm{DCM}(3 \times 0.5 \mathrm{~mL}), \mathrm{MeOH}(3 \times 0.5 \mathrm{~mL})$ and ether $(3 \times 0.5 \mathrm{~mL})$, and then dried in vacuo. Resin $\mathbf{1 0 a}(19.3 \mathrm{mg}, 0.0089 \mathrm{mmol})$ and silicaTBD (94.4 mg, $0.089 \mathrm{mmol})$ were suspended in DMF (500 $\mu \mathrm{L})$. DIEA (3.1 $\mu \mathrm{L}, 0.018 \mathrm{mmol})$ was added. After $16 \mathrm{~h}$, resin was washed with DMF $(3 \times 0.5 \mathrm{~mL})$. Combined cleavage solution and washes were brought to $2.0 \mathrm{~mL}$ final volume in a volumetric flask.

General procedure for HPLC-UV determination of experimental yields. Cleavage aliquot $(25 \mu \mathrm{L})$ and $450 \mu \mathrm{M}$ solution of (+/-)- $\gamma$-(2-naphthyl)- $\gamma$-butyrolactone $(75 \mu \mathrm{L}, \mathrm{RF}=0.98)$ were diluted in 3:1 acetonitrile:water $(750 \mu \mathrm{L})$. Samples were analyzed on a Beckman-Coulter System Gold HPLC equipped with a Phenomenex Jupiter C18 column $(250 \times 4.60 \mathrm{~mm}, 5 \mu \mathrm{m})$ using a 5-95\% acetonitrile in water over a 25 minute gradient. Integration of the absorbancies at $280 \mathrm{~nm}$ gave the experimental yield. 


\section{Solid-Phase Synthesis of Acrylamides}
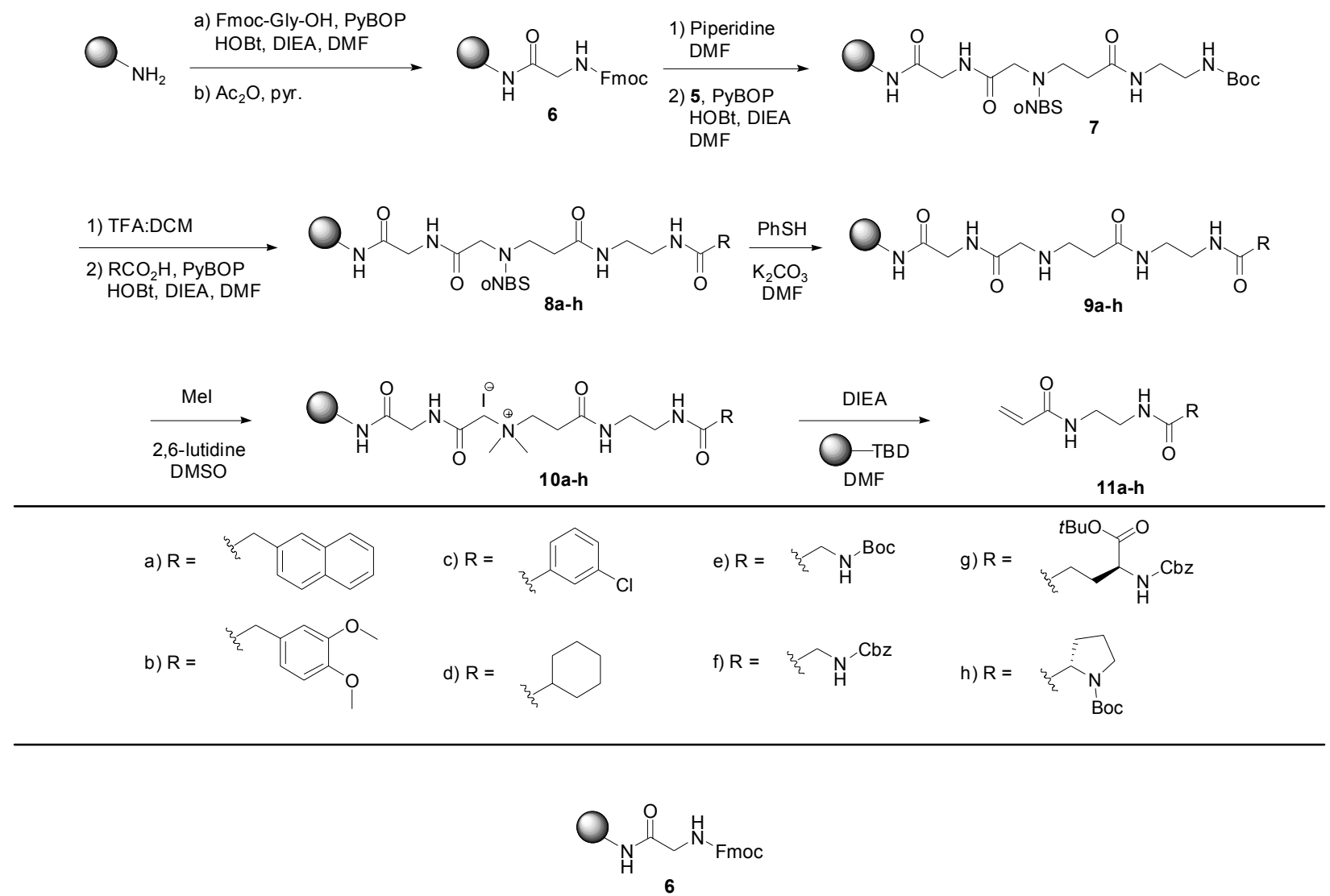

Resin 6. Resin 6 was prepared as previously described (vide supra), and the loading level was determined to be $0.52 \mathrm{mmol} / \mathrm{g}$ by Fmoc analysis. ${ }^{3}$

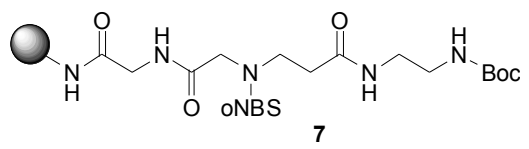

Resin 7. Resin 6 (1.1379 g, $0.59 \mathrm{mmol})$ was treated with $20 \%$ piperidine in DMF in two approximately equal batches for $30 \mathrm{~min}(2 \times 5 \mathrm{~mL})$, then washed with DMF $(3 \times 3 \mathrm{~mL})$, DCM $(3$ $\times 3 \mathrm{~mL}), \operatorname{DMF}(3 \times 3 \mathrm{~mL}), \mathrm{DCM}(3 \times 3 \mathrm{~mL}), \mathrm{MeOH}(3 \times 3 \mathrm{~mL})$ and ether $(3 \times 3 \mathrm{~mL})$, and then dried. To a solution of 5 (564.4 mg, $1.189 \mathrm{mmol})$ in DMF $(1.1 \mathrm{~mL})$ was added PyBOP (681.7 $\mathrm{mg}, 1.310 \mathrm{mmol})$ in DMF (1.35 mL), HOBt (162.9 mg, $1.206 \mathrm{mmol})$ in DMF $(0.3 \mathrm{~mL})$ and then DIEA $(311 \mu \mathrm{L}, 1.79 \mathrm{mmol})$. This solution was added to deprotected resin 6 pre-swollen in DMF $(5.0 \mathrm{~mL})$. After $29 \mathrm{~h}$, the Kaiser test indicated complete acylation of amines on resin. The resin was washed in two batches with DMF $(3 \times 3 \mathrm{~mL}), \mathrm{DCM}(3 \times 3 \mathrm{~mL}), \mathrm{DMF}(3 \times 3 \mathrm{~mL}), \mathrm{DCM}(3$ $\times 3 \mathrm{~mL}), \mathrm{MeOH}(3 \times 3 \mathrm{~mL})$ and ether $(3 \times 3 \mathrm{~mL})$, and then dried in vacuo. FT-IR (ATR) 3310 , $2930,1660,1544,1453,1366,1250,1165 \mathrm{~cm}^{-1}$. 


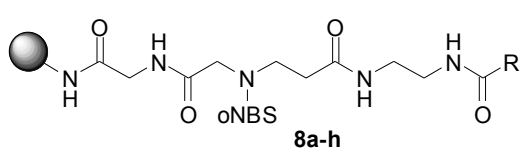

General procedure for preparation of resins 8a-h. Resin 7 (76.1 mg, $0.035 \mathrm{mmol})$ was treated with wet 1:1 TFA:DCM $(1.0 \mathrm{~mL})$ for $1 \mathrm{~h}$, then washed with DCM $(3 \times 1 \mathrm{~mL}), 5 \%$ DIEA in $\operatorname{DCM}(3 \times 1 \mathrm{~mL}), \operatorname{DCM}(3 \times 1 \mathrm{~mL}), \operatorname{DMF}(3 \times 1 \mathrm{~mL}), \operatorname{DCM}(3 \times 1 \mathrm{~mL}), \operatorname{MeOH}(3 \times 1 \mathrm{~mL})$ and ether $(3 \times 1 \mathrm{~mL})$, and then dried. To a solution of $\mathrm{RCO}_{2} \mathrm{H}(0.070 \mathrm{mmol})$ in DMF $(50 \mu \mathrm{L})$ was added PyBOP (40.1 mg, $0.0771 \mathrm{mmol})$ in DMF (125 $\mu \mathrm{L})$, HOBt (9.5 mg, $0.070 \mathrm{mmol})$ in DMF $(30 \mu \mathrm{L})$ and then DIEA $(18 \mu \mathrm{L}, 0.10 \mathrm{mmol})$. This solution was added to deprotected resin 7 pre-swollen in DMF $(365 \mu \mathrm{L})$. After $17 \mathrm{~h}$, the Kaiser test indicated complete acylation of amines on resin. The resin was washed with DMF $(3 \times 1 \mathrm{~mL}), \mathrm{DCM}(3 \times 1 \mathrm{~mL}), \mathrm{DMF}(3 \times 1$ $\mathrm{mL}), \operatorname{DCM}(3 \times 1 \mathrm{~mL}), \mathrm{MeOH}(3 \times 1 \mathrm{~mL})$ and ether $(3 \times 1 \mathrm{~mL})$, and then dried in vacuo.

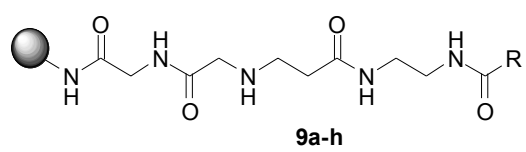

General procedure for preparation of resins 9a-h. The oNBS deprotection reagent was prepared as previously described (vide supra). Resins 8a-h $(0.035 \mathrm{mmol})$ were treated with the oNBS deprotection reagent (CAUTION: STENCH) for $10 \mathrm{~min}(3 \times 0.75 \mathrm{~mL})$. A bright yellow solution was indicative of oNBS deprotection. The resin was washed with DMF $(3 \times 1 \mathrm{~mL})$, $\operatorname{DCM}(3 \times 1 \mathrm{~mL}), \operatorname{DMF}(3 \times 1 \mathrm{~mL}), \mathrm{DCM}(3 \times 1 \mathrm{~mL}), 5 \%$ DIEA in DCM $(3 \times 1 \mathrm{~mL}), \mathrm{DCM}(3 \times$ $1 \mathrm{~mL}), \mathrm{MeOH}(3 \times 1 \mathrm{~mL})$ and ether $(3 \times 1 \mathrm{~mL})$, and then dried in vacuo. The disappearance of FT-IR (ATR) bands at 1366, 1250, and $1165 \mathrm{~cm}^{-1}$ confirmed removal of oNBS protecting group.

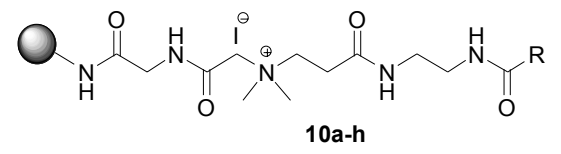

General procedure for preparation of resins $\mathbf{1 0 a}-\mathbf{h}$. To resins $9 \mathbf{a}-\mathbf{h}(0.035 \mathrm{mmol})$, pre-swollen in DMSO $(0.7 \mathrm{~mL})$, was added 2,6-lutidine $(153 \mu \mathrm{L}, 1.40 \mathrm{mmol})$ and iodomethane $(87 \mu \mathrm{L}, 1.4$ mmol). After $3 \mathrm{~h}$, resin was washed with DMF $(3 \times 1 \mathrm{~mL}), \operatorname{DCM}(3 \times 1 \mathrm{~mL}), \operatorname{DMF}(3 \times 1 \mathrm{~mL})$, $\mathrm{DCM}(3 \times 1 \mathrm{~mL}), \mathrm{MeOH}(3 \times 1 \mathrm{~mL})$ and ether $(3 \times 1 \mathrm{~mL})$, and then dried in vacuo.

General procedure for synthesis of acrylamides 11a-h. To a suspension of resins 10a-h $(0.035 \mathrm{mmol})$ and PS-TBD $(134.6 \mathrm{mg}, 0.35 \mathrm{mmol})$ in DMF $(1.0 \mathrm{~mL})$ was added DIEA $(12.2 \mu \mathrm{L}$, $0.0700 \mathrm{mmol})$. After $21 \mathrm{~h}$, the resin was washed with DMF $(3 \times 0.75 \mathrm{~mL})$, and the cleavage solution and combined resin washes were evaporated to give acrylamides 11a-h. 


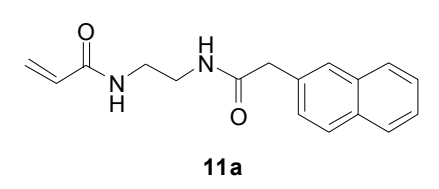

Acrylamide 11a. $6.05 \mathrm{mg} \mathrm{(63 \% )} \mathrm{as} \mathrm{a} \mathrm{white} \mathrm{solid.} \mathrm{Identical} \mathrm{in} \mathrm{all} \mathrm{respects} \mathrm{to} \mathrm{11a} \mathrm{prepared}$ during optimization of linker chemistry and solution-phase route (vide infra).

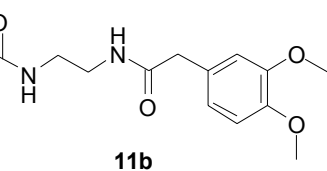

Acrylamide 11b. $6.46 \mathrm{mg}$ (64\%) as an orange solid. FT-IR (ATR) 3284, 1642, 1625, 1560, $1515,1451,1241,1140,1027 \mathrm{~cm}^{-1} ;{ }^{1} \mathrm{H}$ NMR (DMSO- $\left.d_{6}, 300 \mathrm{MHz}\right) \delta 8.15(\mathrm{t}, J=4.4 \mathrm{~Hz}, 1 \mathrm{H})$, $8.02(\mathrm{t}, J=4.6 \mathrm{~Hz}, 1 \mathrm{H}), 6.86(\mathrm{~m}, 2 \mathrm{H}), 6.75(\mathrm{~d}, J=8.2 \mathrm{~Hz}, 1 \mathrm{H}), 6.19$ (dd, $J=17.2,9.9 \mathrm{~Hz}, 1 \mathrm{H})$, 6.07 (dd, $J=17.2,2.6 \mathrm{~Hz}, 1 \mathrm{H}), 5.58$ (dd, $J=9.8,2.4 \mathrm{~Hz}, 1 \mathrm{H}), 3.73$ (s, 3H), 3.71 (s, $3 \mathrm{H}), 3.31$ (s, 2H), 3.15 (m, 4H); ${ }^{13} \mathrm{C}$ NMR (DMSO- $\left.d_{6}, 75 \mathrm{MHz}\right) \delta 170.55,164.73,148.43,147.42,131.72$, $128.65,125.01,120.94,112.92,111.75,55.51,55.37,41.97,38.37$ (2C); MS (HRESI-MS) calculated for $\left[\mathrm{C}_{15} \mathrm{H}_{20} \mathrm{~N}_{2} \mathrm{O}_{4}+\mathrm{Na}\right]^{+}$315.1321, found 315.1317.

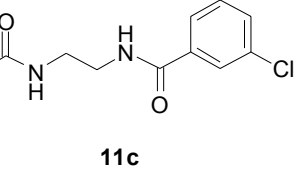

Acrylamide 11c. $6.10 \mathrm{mg}$ (69\%) as an orange solid. FT-IR (ATR) 3286, 1644, 1628, 1545, 1480, 1334, $1249 \mathrm{~cm}^{-1} ;{ }^{1} \mathrm{H}$ NMR (DMSO- $d_{6}, 300 \mathrm{MHz}$ ) $\delta 8.68$ (s (broad), $1 \mathrm{H}$ ), 8.25 (s (broad), $1 \mathrm{H}), 7.89(\mathrm{~d}, J=1.4 \mathrm{~Hz}, 1 \mathrm{H}), 7.80$ (dd, $J=7.6,1.4 \mathrm{~Hz}, 1 \mathrm{H}), 7.61(\mathrm{dd}, J=8.1,1.1 \mathrm{~Hz}, 1 \mathrm{H}), 7.51$ (t, $J=7.8 \mathrm{~Hz}, 1 \mathrm{H}), 6.21(\mathrm{dd}, J=17.3,10.0 \mathrm{~Hz}, 1 \mathrm{H}), 6.08$ (dd, $J=17.1,2.6 \mathrm{~Hz}, 1 \mathrm{H}), 5.59$ (dd, $J$ $=10.0,2.6 \mathrm{~Hz}, 1 \mathrm{H}), 3.33(\mathrm{~m}, 4 \mathrm{H}) ;{ }^{13} \mathrm{C}$ NMR $\left(\mathrm{DMSO}-d_{6}, 75 \mathrm{MHz}\right) \delta 164.93,164.85,136.45$, 133.08, 131.76, 130.92, 130.24, 127.01, 125.93, 125.05, 38.12 (2C); MS (HRESI-MS) calculated for $\left[\mathrm{C}_{12} \mathrm{H}_{13} \mathrm{ClN}_{2} \mathrm{O}_{2}+\mathrm{Na}\right]^{+}$275.0563, found 275.0560.

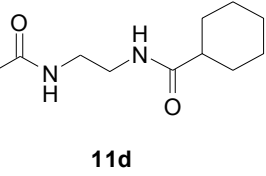

Acrylamide 11d. $5.51 \mathrm{mg}$ (69\%) as a yellowish-white solid. FT-IR (ATR) 3297, 1661, 1643, 1628, 1446, 1448, 1248, $949 \mathrm{~cm}^{-1} ;{ }^{1} \mathrm{H}$ NMR $\left(\mathrm{CDCl}_{3}, 300 \mathrm{MHz}\right) \delta 6.64$ (s (broad), 1H), $6.28(\mathrm{~s}$ (broad), 1H), 6.26 (dd, $J=17.0,1.6 \mathrm{~Hz}, 1 \mathrm{H}), 6.11$ (dd, $J=17.0,10.1 \mathrm{~Hz}, 1 \mathrm{H}), 5.65$ (dd, $J=10.1$, $1.5 \mathrm{~Hz}, 1 \mathrm{H}), 3.45$ (m, 4H), 2.09 (tt, $J=11.7,3.4 \mathrm{~Hz}, 1 \mathrm{H}), 1.80(\mathrm{~m}, 4 \mathrm{H}), 1.67(\mathrm{~m}, 1 \mathrm{H}), 1.31$ (m, 
$5 \mathrm{H}) ;{ }^{13} \mathrm{C}$ NMR (CDCl3, $\left.75 \mathrm{MHz}\right) \delta 177.79,166.66,130.79,126.45,45.38,40.55,39.71,29.61$

(2C), 25.67 (3C); MS (HRESI-MS) calculated for $\left[\mathrm{C}_{12} \mathrm{H}_{20} \mathrm{~N}_{2} \mathrm{O}_{2}+\mathrm{Na}\right]^{+} 247.1422$, found 247.1420.

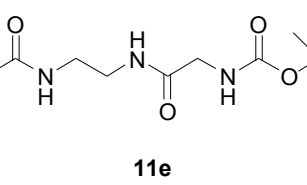

Acrylamide 11e. $6.85 \mathrm{mg}(73 \%)$ as an orange oil. FT-IR (thin film) 3298, 1661, 1540, 1248, $1168 \mathrm{~cm}^{-1} ;{ }^{1} \mathrm{H}$ NMR $\left(\mathrm{CDCl}_{3}, 300 \mathrm{MHz}\right) \delta 6.94$ (s (broad), 1H), 6.65 (s (broad), 1H), 6.28 (dd, $J$ $=17.2,1.7 \mathrm{~Hz}, 1 \mathrm{H}), 6.12(\mathrm{dd}, J=16.9,10.0 \mathrm{~Hz}, 1 \mathrm{H}), 5.65(\mathrm{dd}, J=10.2,1.6 \mathrm{~Hz}, 1 \mathrm{H}), 5.29(\mathrm{t}, J=$ $5.2 \mathrm{~Hz}, 1 \mathrm{H}), 3.78(\mathrm{~d}, J=5.8 \mathrm{~Hz}, 2 \mathrm{H}), 3.47(\mathrm{~m}, 4 \mathrm{H}), 1.45(\mathrm{~s}, 9 \mathrm{H}) ;{ }^{13} \mathrm{C} \mathrm{NMR}_{\left(\mathrm{CDCl}_{3}, 75 \mathrm{MHz}\right) \delta}$ 170.73, 166.51, 156.12, 130.71, 126.58, 80.43, 44.42, 39.95, 39.75, 28.31 (3C); MS (HRESIMS) calculated for $\left[\mathrm{C}_{12} \mathrm{H}_{21} \mathrm{~N}_{3} \mathrm{O}_{4}+\mathrm{Na}\right]^{+} 294.1430$, found 294.1441 .

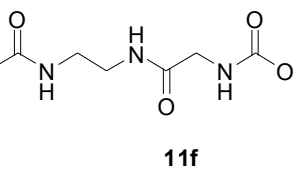

Acrylamide 11f. $6.64 \mathrm{mg}(64 \%)$ as a yellowish-white solid. FT-IR (ATR) 3332, 3285, 1690, 1656, 1541, 1293, $1249 \mathrm{~cm}^{-1}$; ${ }^{1} \mathrm{H}$ NMR (DMSO- $\left.d_{6}, 300 \mathrm{MHz}\right) \delta 8.14$ (s (broad), $\left.1 \mathrm{H}\right), 7.96(\mathrm{~s}$ (broad), 1H), 7.44 (t, $J=5.7 \mathrm{~Hz}, 1 \mathrm{H}), 7.36(\mathrm{~m}, 5 \mathrm{H}), 6.19$ (dd, $J=17.1,9.7 \mathrm{~Hz}, 1 \mathrm{H}), 6.07$ (dd, $J=$ 17.1, $2.5 \mathrm{~Hz}, 1 \mathrm{H}), 5.58$ (dd, $J=9.5,2.6 \mathrm{~Hz}, 1 \mathrm{H}), 5.03(\mathrm{~s}, 2 \mathrm{H}), 3.58$ (d, $J=6.1 \mathrm{~Hz}, 2 \mathrm{H}), 3.16$ (m, $4 \mathrm{H}) ;{ }^{13} \mathrm{C}$ NMR (DMSO- $\left.d_{6}, 75 \mathrm{MHz}\right) \delta 169.18,164.76,156.39,136.99,131.69,128.29$ (2C), 127.73, 127.67 (2C), 125.05, 65.44, 43.53, 38.33, 38.28; MS (HRESI-MS) calculated for $\left[\mathrm{C}_{15} \mathrm{H}_{19} \mathrm{~N}_{3} \mathrm{O}_{4}+\mathrm{H}\right]^{+}$306.1454, found 306.1450 .

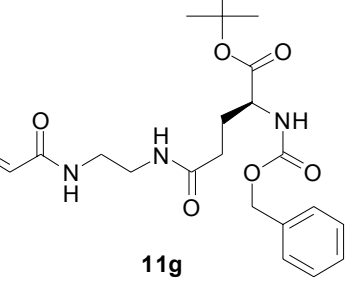

Acrylamide 11g. $10.56 \mathrm{mg}(67 \%)$ as an orange oil. $[\alpha]_{\mathrm{D}}=+19^{\circ}\left(c=0.50, \mathrm{CHCl}_{3}\right)$; FT-IR (thin film) 3294, 1720, 1659, 1540, 1247, 1155, $1055 \mathrm{~cm}^{-1} ;{ }^{1} \mathrm{H}$ NMR $\left(\mathrm{CDCl}_{3}, 300 \mathrm{MHz}\right) \delta 7.35(\mathrm{~m}$, $5 \mathrm{H}), 6.81$ (s (broad), 1H), 6.51 (s (broad), 1H), 6.27 (dd, $J=16.9,1.8 \mathrm{~Hz}, 1 \mathrm{H}), 6.12$ (dd, $J=$ 16.9, $10.2 \mathrm{~Hz}, 1 \mathrm{H}), 5.66$ (d, $J=8.2 \mathrm{~Hz}, 1 \mathrm{H}), 5.61$ (dd, $J=10.0,1.7 \mathrm{~Hz}, 1 \mathrm{H}), 5.10$ (s, 2H), 4.19 
(td, $J=8.7,2.8 \mathrm{~Hz}, 1 \mathrm{H}), 3.49(\mathrm{~m}, 3 \mathrm{H}), 3.29(\mathrm{~m}, 1 \mathrm{H}), 2.25(\mathrm{~m}, 3 \mathrm{H}), 1.85(\mathrm{~m}, 1 \mathrm{H}), 1.46(\mathrm{~s}, 9 \mathrm{H})$;

${ }^{13} \mathrm{C} \mathrm{NMR}\left(\mathrm{CDCl}_{3}, 75 \mathrm{MHz}\right) \delta 172.96,171.03,166.28,156.44,136.14,130.85,128.55$ (2C), 128.25, 127.99 (2C), 126.32, 82.66, 67.09, 53.72, 39.97, 39.79, 32.35, 29.10, 27.95 (3C); MS (HRESI-MS) calculated for $\left[\mathrm{C}_{22} \mathrm{H}_{31} \mathrm{~N}_{3} \mathrm{O}_{6}+\mathrm{Na}\right]^{+} 456.2111$, found 456.2131 .

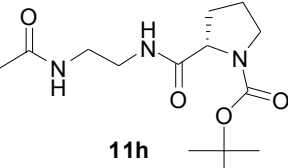

Acrylamide 11h. $7.65 \mathrm{mg}(70 \%)$ as an orange oil. $[\alpha]_{\mathrm{D}}=-30.3^{\circ}\left(c=0.330, \mathrm{CHCl}_{3}\right)$; FT-IR (thin film) 3296, 1664, 1542, 1404, 1246, 1164; ${ }^{1} \mathrm{H}$ NMR $\left(\mathrm{CDCl}_{3}, 300 \mathrm{MHz}\right) \delta 6.88$ (s (broad), 1H), 6.70 (s (broad), 1H), 6.27 (dd, $J=17.0,1.8 \mathrm{~Hz}, 1 \mathrm{H}), 6.12$ (dd, $J=17.0,10.1 \mathrm{~Hz}, 1 \mathrm{H}), 5.63$ (dd, $J=10.1,1.2 \mathrm{~Hz}, 1 \mathrm{H}), 4.20$ (dd, $J=7.8,4.1 \mathrm{~Hz}, 1 \mathrm{H}), 3.43$ (m, 6H), 2.02 (m, 4H), 1.46 (s, $9 \mathrm{H}) ;{ }^{13} \mathrm{C}$ NMR $\left(\mathrm{CDCl}_{3}, 125 \mathrm{MHz}\right)$ major rotamer, $\delta 173.50,166.03,155.69,130.99,126.09$, 80.55, 60.48, 47.29, 39.74, 39.36, 28.41 (3C), 24.58, 20.71; minor rotamer, $\delta 126.53,61.18$, $46.86,40.87,31.18,28.90,23.66$; MS (HRESI-MS) calculated for $\left[\mathrm{C}_{15} \mathrm{H}_{25} \mathrm{~N}_{3} \mathrm{O}_{4}+\mathrm{Na}\right]^{+}$ 334.1743, found 334.1743.

\section{Solution Phase Synthesis of 11a}
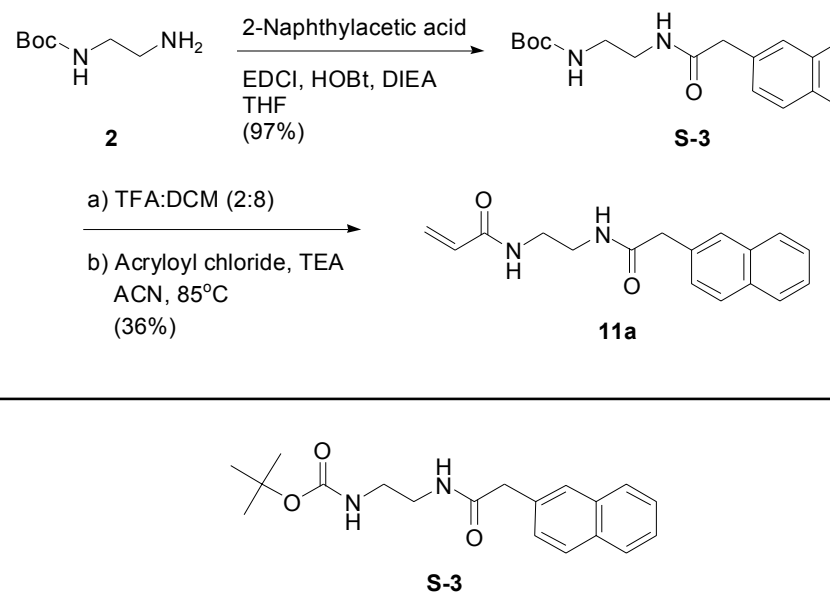

$N$-Boc-ethylenediamine naphthyl acetamide S-3. To a solution of 2 (1.0706 g, $6.6821 \mathrm{mmol})$, 2-naphthyl acetic acid (1.3436 g, $7.2155 \mathrm{mmol}), \mathrm{HOBt}(976.6 \mathrm{mg}, 7.227 \mathrm{mmol})$ and EDCI $(1.6154 \mathrm{~g}, 8.4263 \mathrm{mmol})$ in THF was added DIEA $(3.15 \mathrm{~mL}, 18.1 \mathrm{mmol})$. After $17 \mathrm{~h}$, the solvent was removed. The yellow oily residue was taken up in EtOAc $(120 \mathrm{~mL})$ then washed with $1 \mathrm{~N} \mathrm{HCl}(3 \times 60 \mathrm{~mL})$, water $(60 \mathrm{~mL})$, saturated $\mathrm{NaHCO}_{3}(3 \times 60 \mathrm{~mL})$, water $(60 \mathrm{~mL})$ and brine $(60 \mathrm{~mL})$. The organic layer was dried $\left(\mathrm{Na}_{2} \mathrm{SO}_{4}\right)$, filtered and evaporated to give $2.1315 \mathrm{~g}$ 
(97\%) of S-3 as a white solid. $\mathrm{R}_{f}=0.52$ (10\% MeOH in DCM); FT-IR (ATR) 3335, 3298, 3077, 2980, 2937, 1687, 1645, 1554, 1534, 1366, 1280, 1248, 1174, 985, 861, $760 \mathrm{~cm}^{-1}$; ${ }^{1} \mathrm{H} \mathrm{NMR}$ $\left(\mathrm{CDCl}_{3}, 300 \mathrm{MHz}\right) \delta 7.82(\mathrm{~m}, 3 \mathrm{H}), 7.71(\mathrm{~s}, 1 \mathrm{H}), 7.48(\mathrm{~m}, 2 \mathrm{H}), 7.38(\mathrm{dd}, J=8.5,2.0 \mathrm{~Hz}, 1 \mathrm{H})$, 6.13 (s (broad), 1H), 4.86 (s (broad), 1H), 3.71 (s, 2H), 3.31 (q, $J=5.2 \mathrm{~Hz}, 2 \mathrm{H}), 3.19$ (q, $J=5.7$ $\mathrm{Hz}, 2 \mathrm{H}), 1.36$ (s, 9H); ${ }^{13} \mathrm{C}$ NMR (DMSO-d 6 , $\left.75 \mathrm{MHz}\right) \delta 171.62,156.68,133.52,132.50,132.22$, 128.72, 128.20, 127.67, 127.64, 127.25, 126.33, 125.96, 79.57, 43.93, 40.77, 40.29, 28.26 (3C); MS (HRESI-MS) calculated for $\left[\mathrm{C}_{19} \mathrm{H}_{24} \mathrm{~N}_{2} \mathrm{O}_{3}+\mathrm{Na}\right]^{+} 351.1685$, found 351.1674.

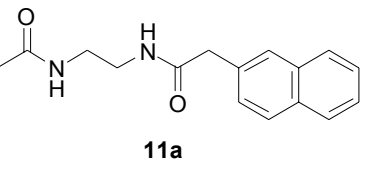

Acrylamide 11a. To a suspension of S-3 $(32.1 \mathrm{mg}, 0.0977 \mathrm{mmol})$ in DCM (400 $\mu \mathrm{L})$ was added TFA $(100 \mu \mathrm{L})$. After $2 \mathrm{~h}$, the solvent was removed and the oily residue evaporated from ether (5 $\times 0.5 \mathrm{~mL})$. The crude deprotection product was purified by FCC (1-15\% $\left.\mathrm{MeOH}: \mathrm{CHCl}_{3}\right)$, then taken directly on to the next step. To a $0{ }^{\circ} \mathrm{C}$ solution of deprotected $\mathbf{S - 3}$ and TEA (61 $\mu \mathrm{L}, 0.44$ $\mathrm{mmol})$ in acetonitrile $(350 \mu \mathrm{L})$ was added a solution of acryloyl chloride $(20 \mu \mathrm{L}, 0.25 \mathrm{mmol})$ in acetonitrile $(250 \mu \mathrm{L})$ dropwise. Upon completion of addition, the reaction was allowed to warm to room temperature. After $6 \mathrm{~h}$, the reaction was quenched by addition of water. The crude product was collected by vacuum filtration, and then washed with $1 \mathrm{~N} \mathrm{HCl}(3 \times 0.5 \mathrm{~mL})$, water $(0.5 \mathrm{~mL})$, sat. $\mathrm{NaHCO}_{3}(3 \times 0.5 \mathrm{~mL})$ and water $(0.5 \mathrm{~mL})$. Trituration with EtOAc followed by washing with ether gave $10.0 \mathrm{mg}(36 \%)$ of $11 \mathrm{a}$ as a white powder. $\mathrm{R}_{f}=0.49(10 \% \mathrm{MeOH}$ in $\mathrm{CHCl}_{3}$ ); FT-IR (ATR) 3245, 3074, 1653, 1632, 1565, 1478, 1409, 1347, 1250, 962, 862, 805, $738 \mathrm{~cm}^{-1} ;{ }^{1} \mathrm{H}$ NMR (DMSO- $\left.d_{6}, 300 \mathrm{MHz}\right) \delta 8.18(\mathrm{~m}, 2 \mathrm{H}), 7.85(\mathrm{~m}, 3 \mathrm{H}), 7.73(\mathrm{~s}, 1 \mathrm{H}), 7.52-7.39$ (m, 3H), $6.19(\mathrm{dd}, J=17.1,9.7 \mathrm{~Hz}, 1 \mathrm{H}), 6.07$ (dd, $J=17.1,2.6 \mathrm{~Hz}, 1 \mathrm{H}), 5.58$ (dd, $J=9.7,2.6$ $\mathrm{Hz}, 1 \mathrm{H}), 3.58(\mathrm{~s}, 2 \mathrm{H}), 3.18(\mathrm{~m}, 4 \mathrm{H}) ;{ }^{13} \mathrm{C} \mathrm{NMR}$ (DMSO-d, $\left.75 \mathrm{MHz}\right) \delta 170.24,164.76,134.00$, 132.96, 131.73 (2C), 127.64, 127.56, 127.43, 127.37, 127.26, 126.01, 125.47, 125.05, 42.50, 38.45, 38.35; MS (HRESI-MS) calculated for $\left[\mathrm{C}_{17} \mathrm{H}_{18} \mathrm{~N}_{2} \mathrm{O}_{2}+\mathrm{Na}\right]^{+}$305.1266, found 305.1260. 


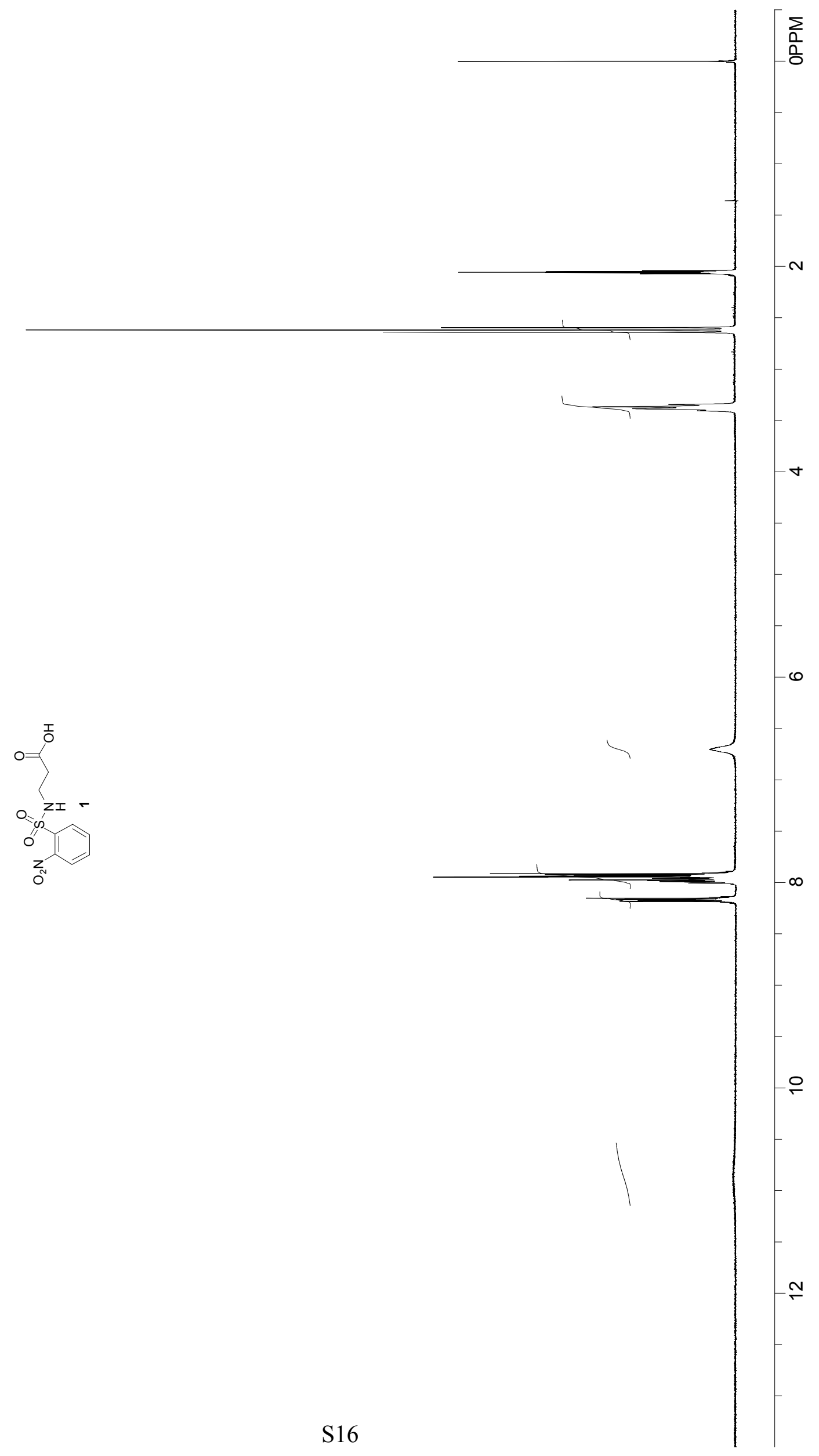




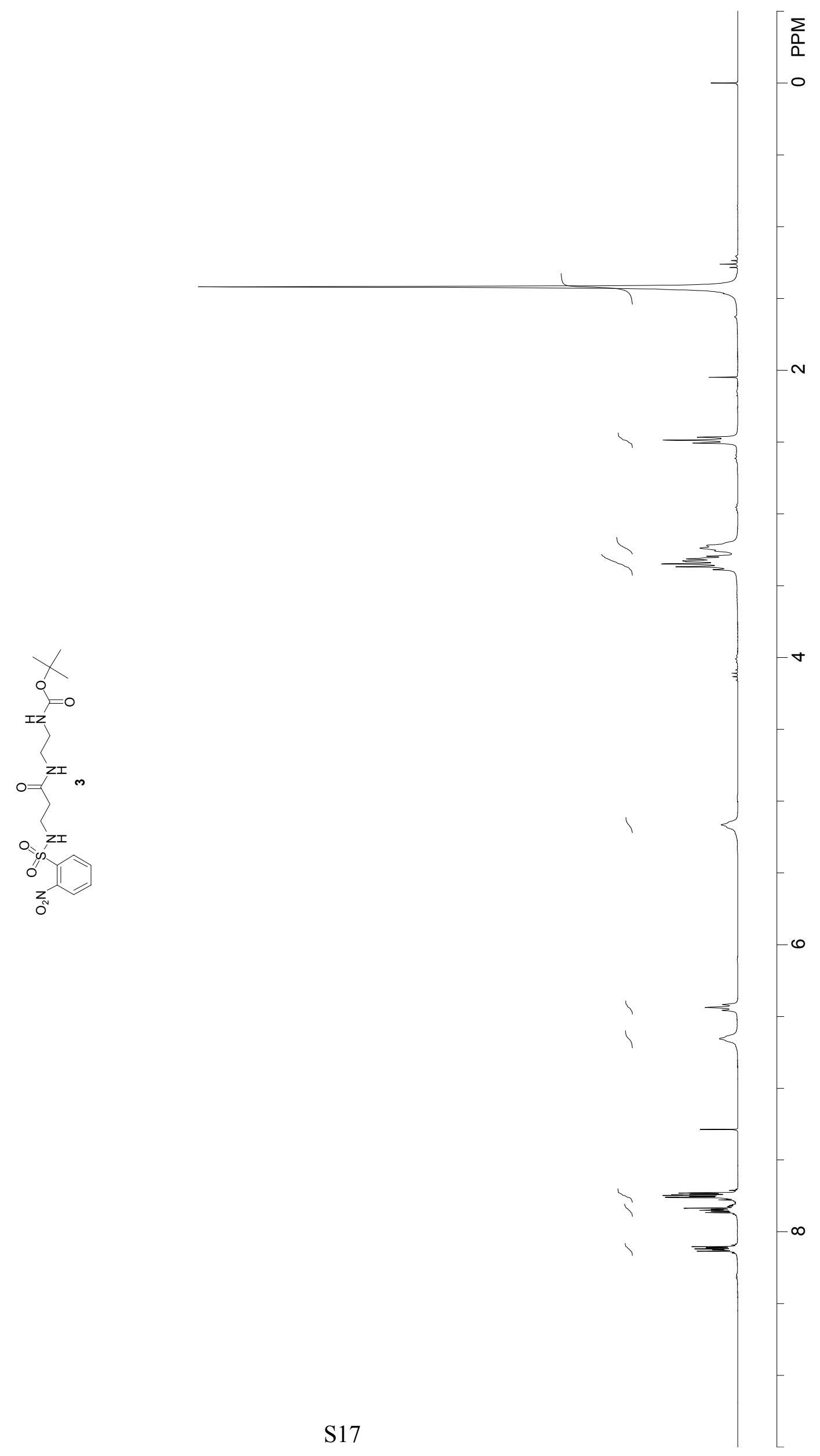




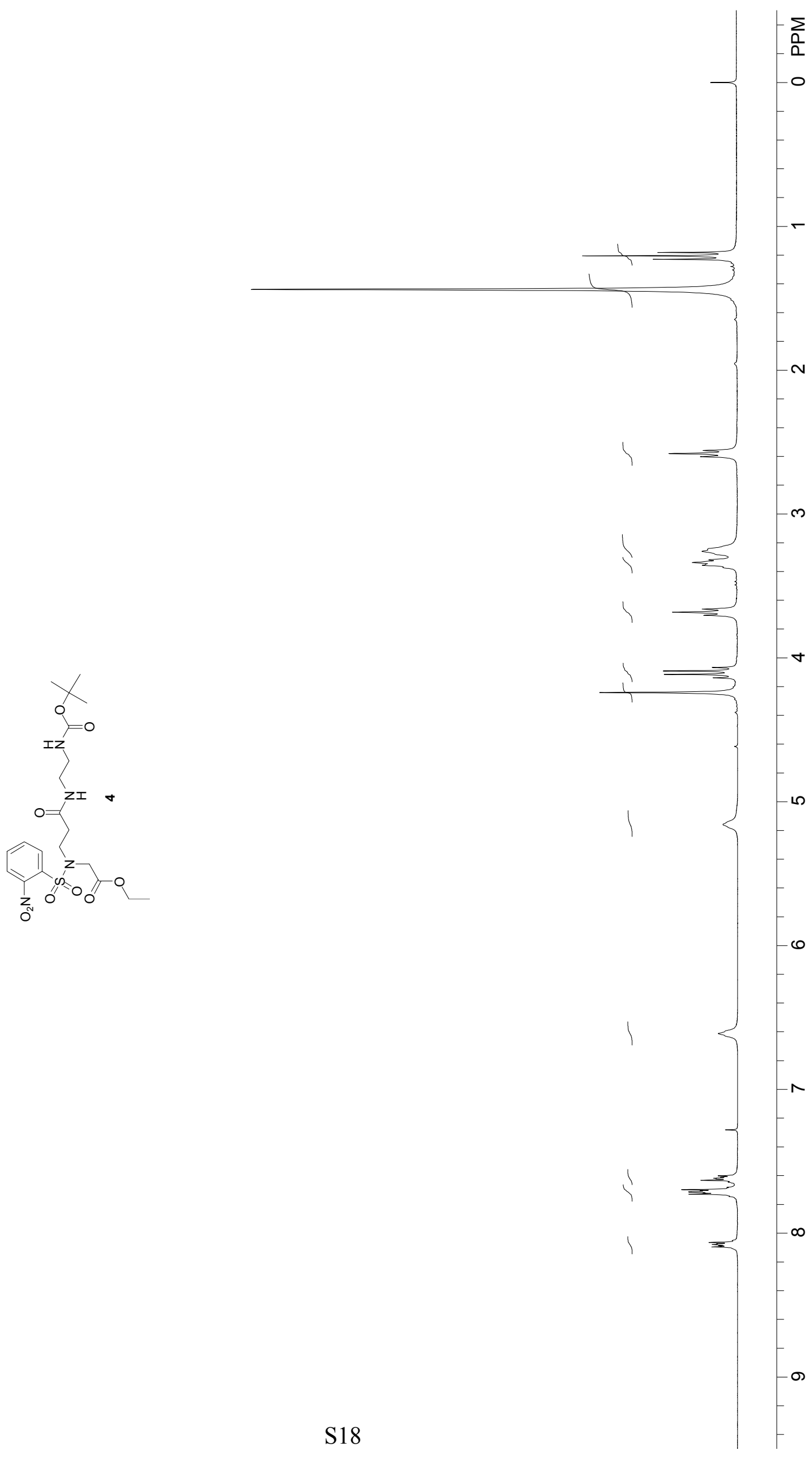




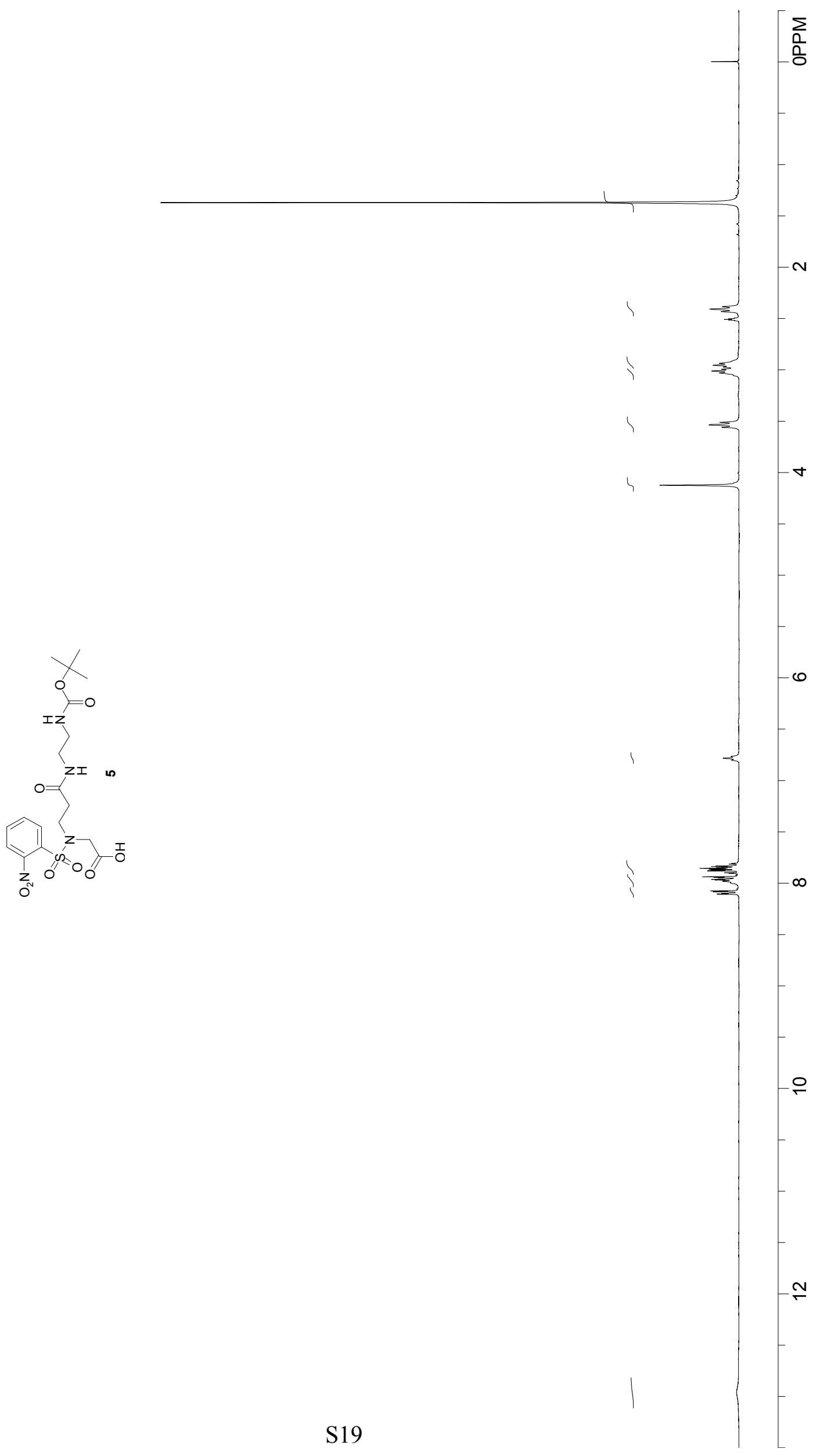




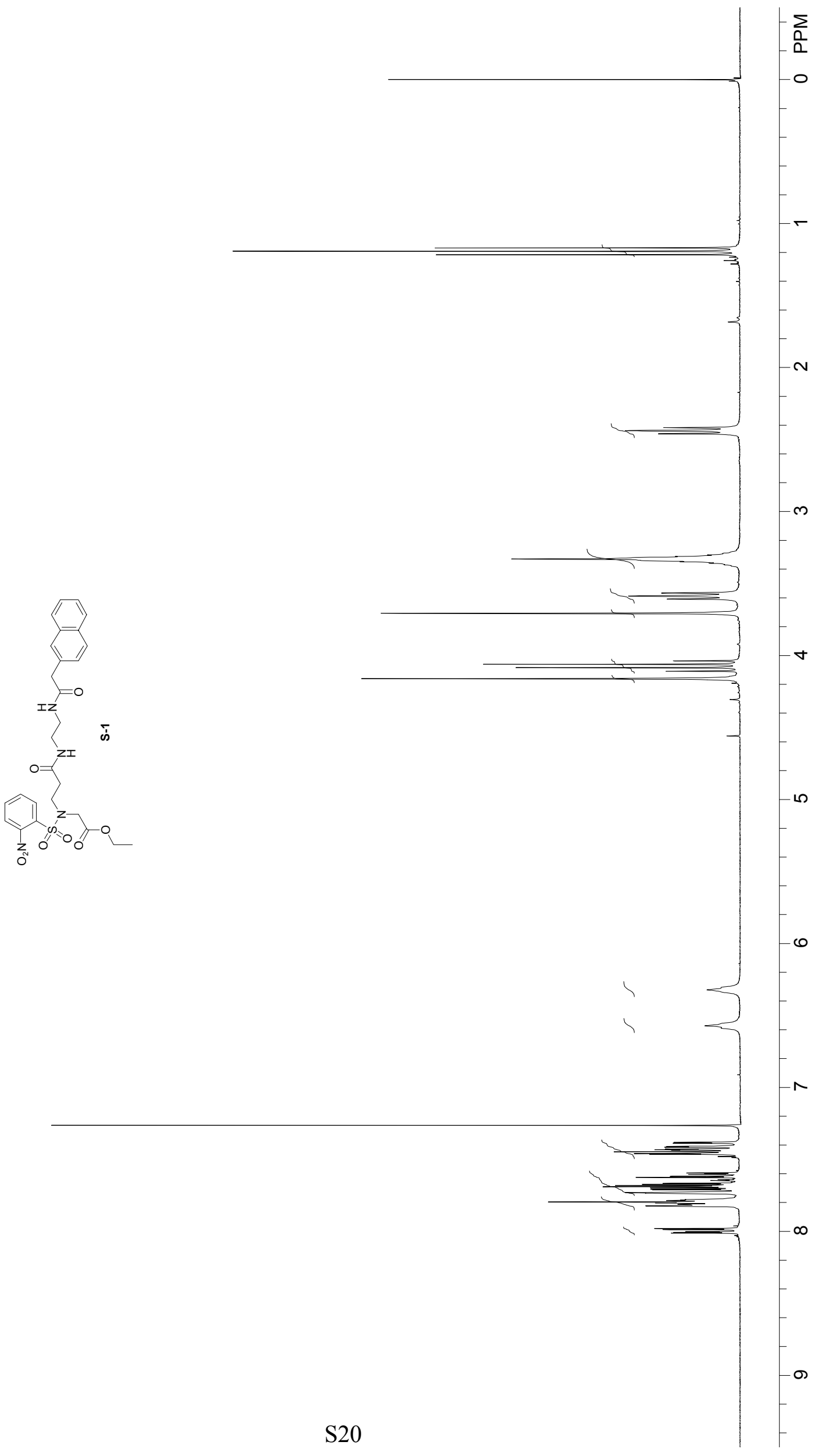




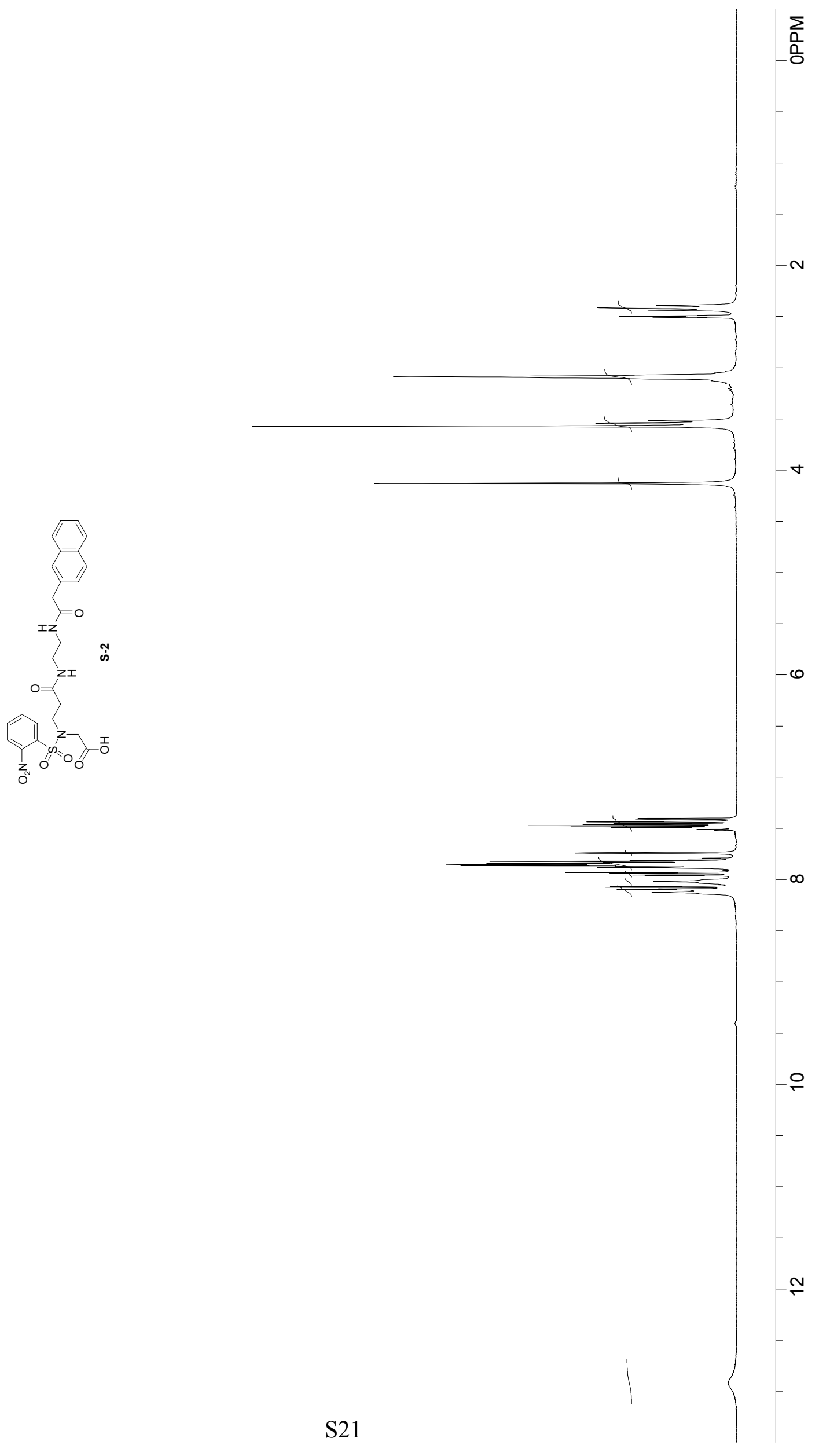




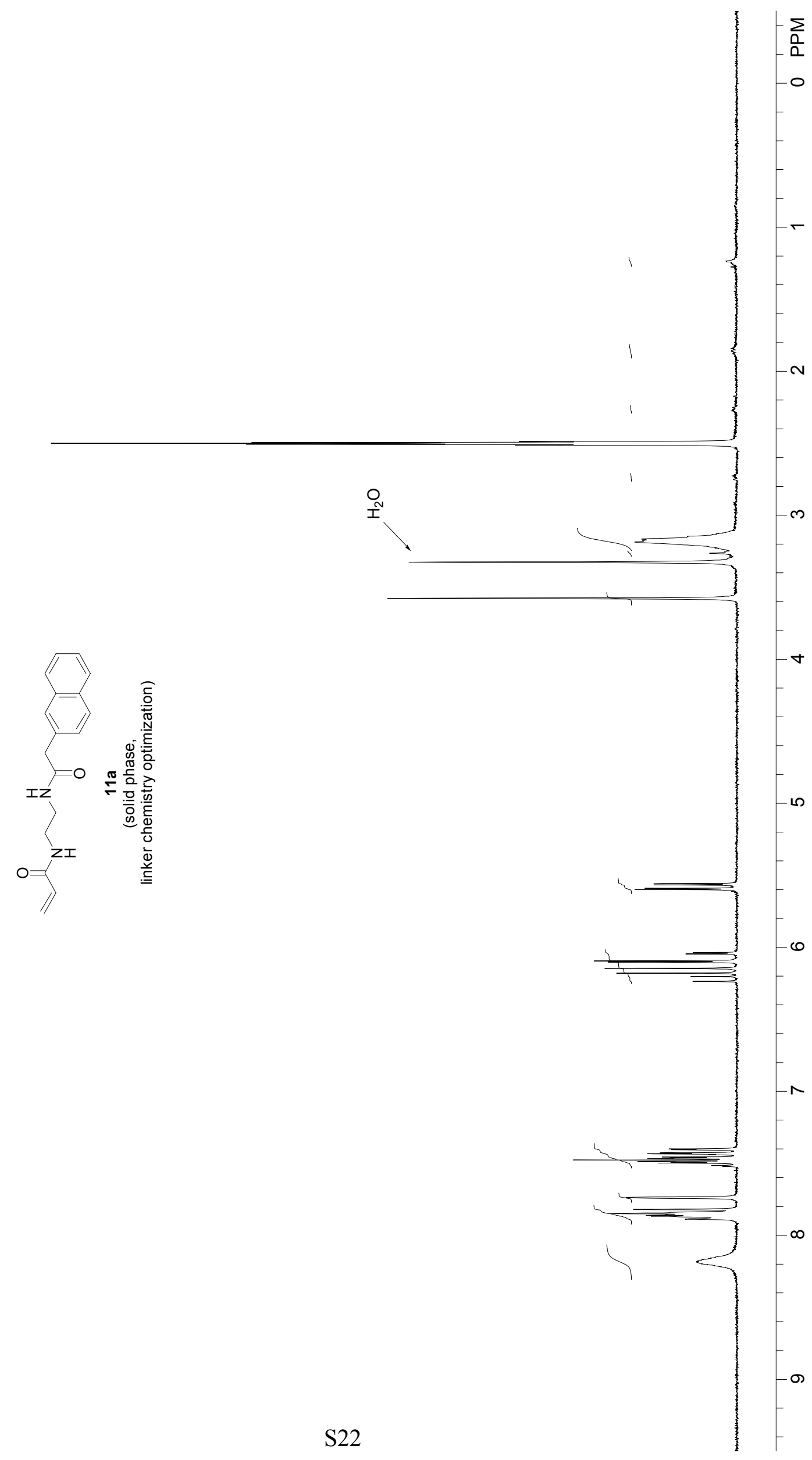




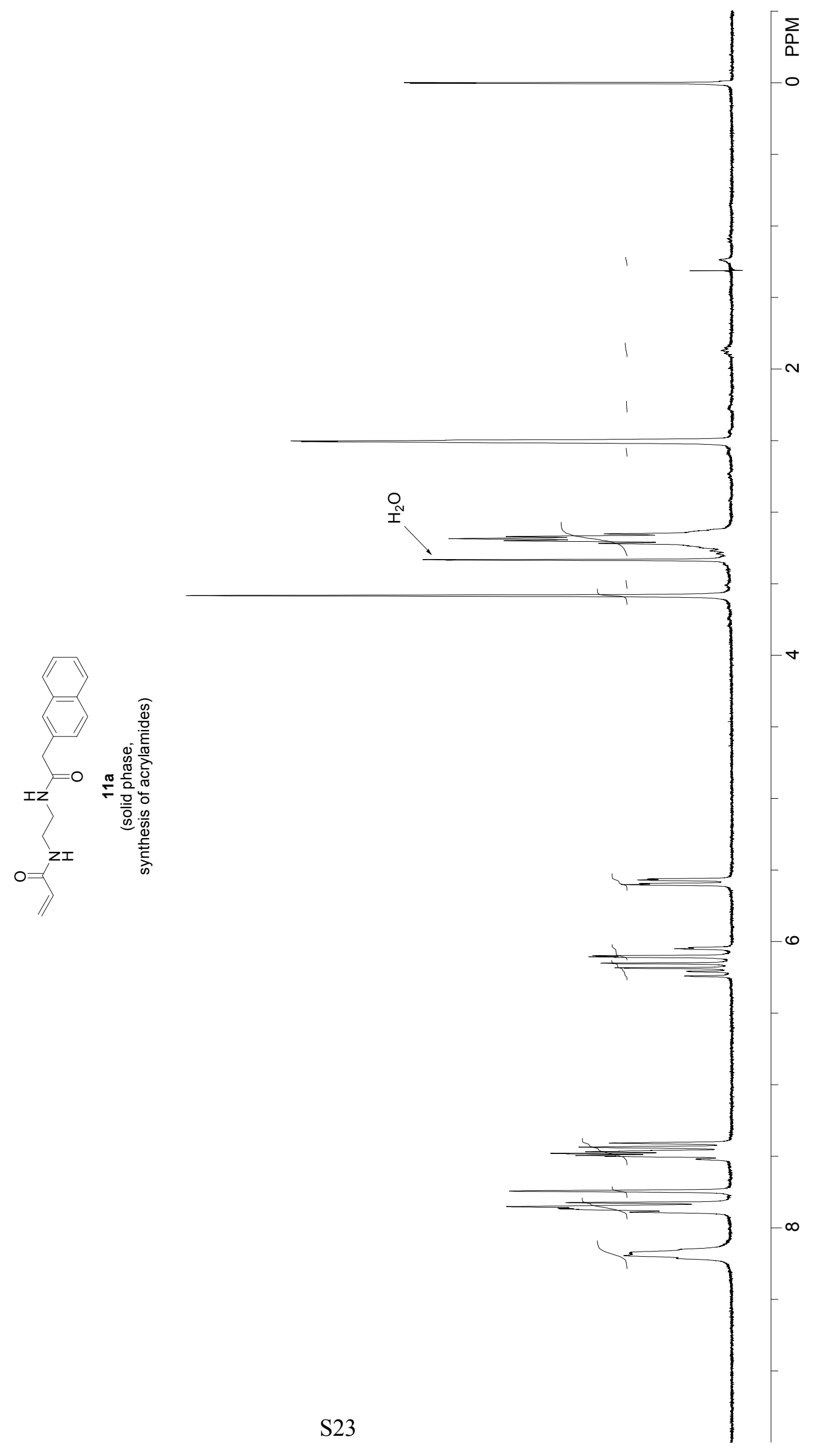




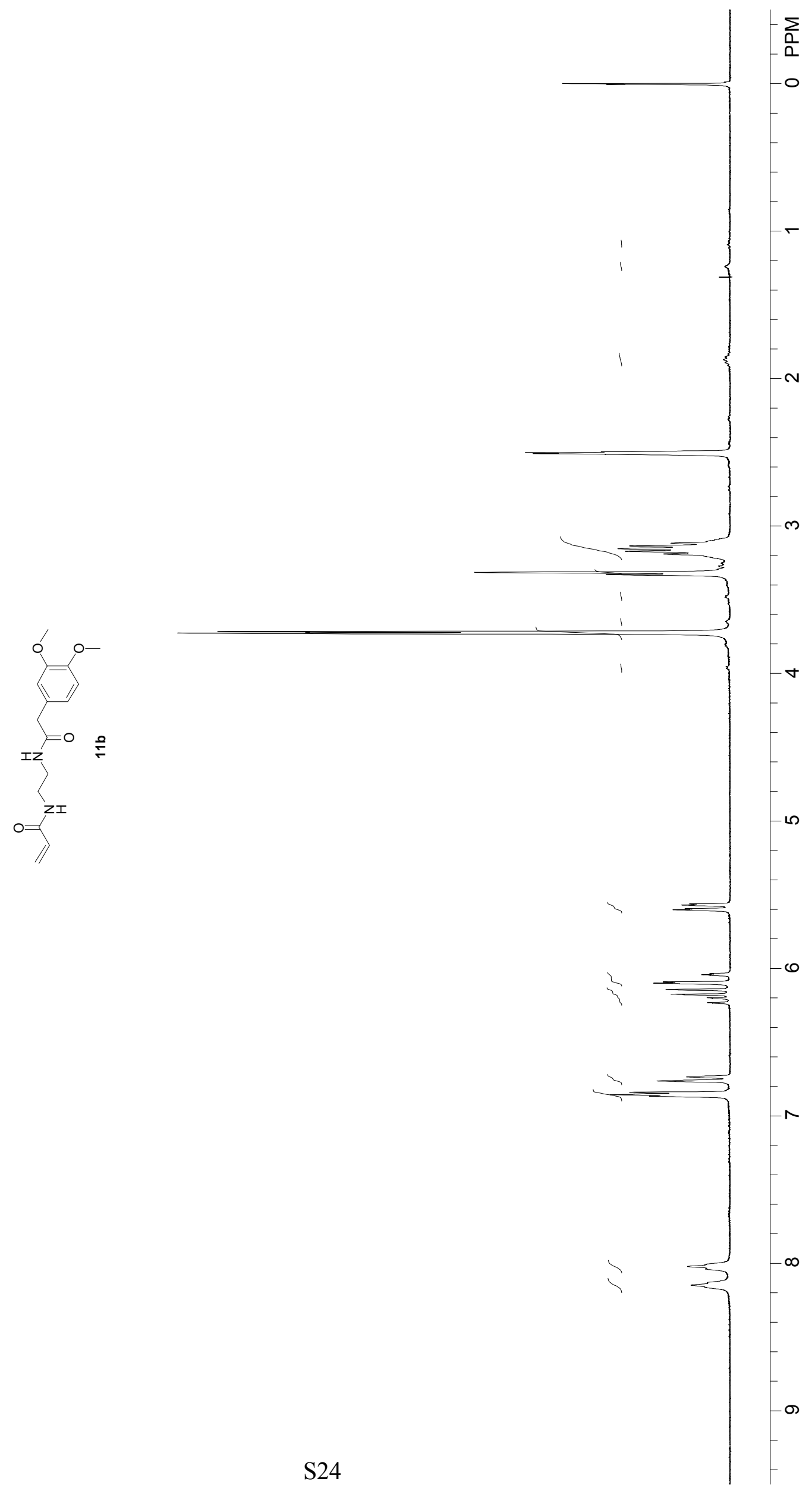




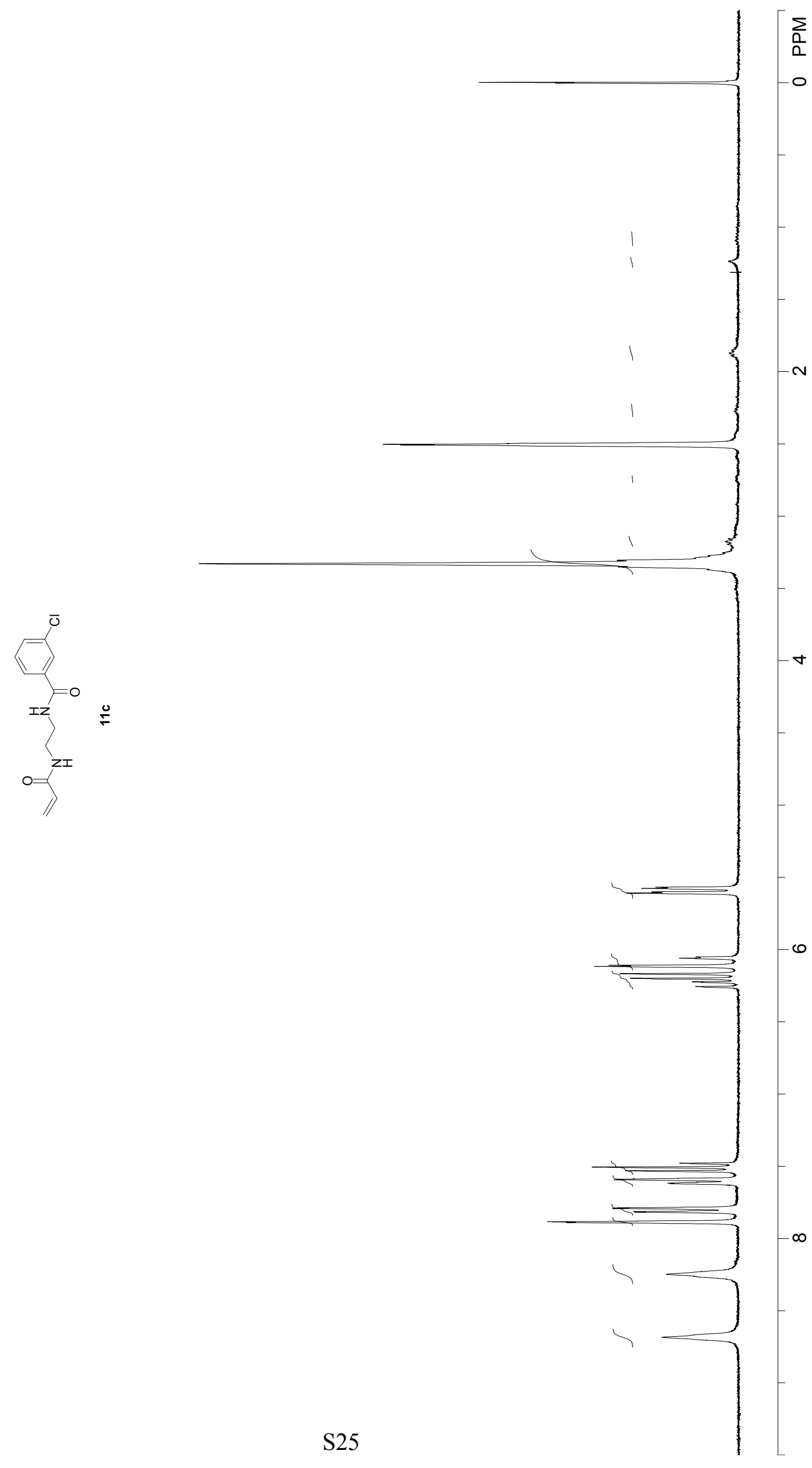




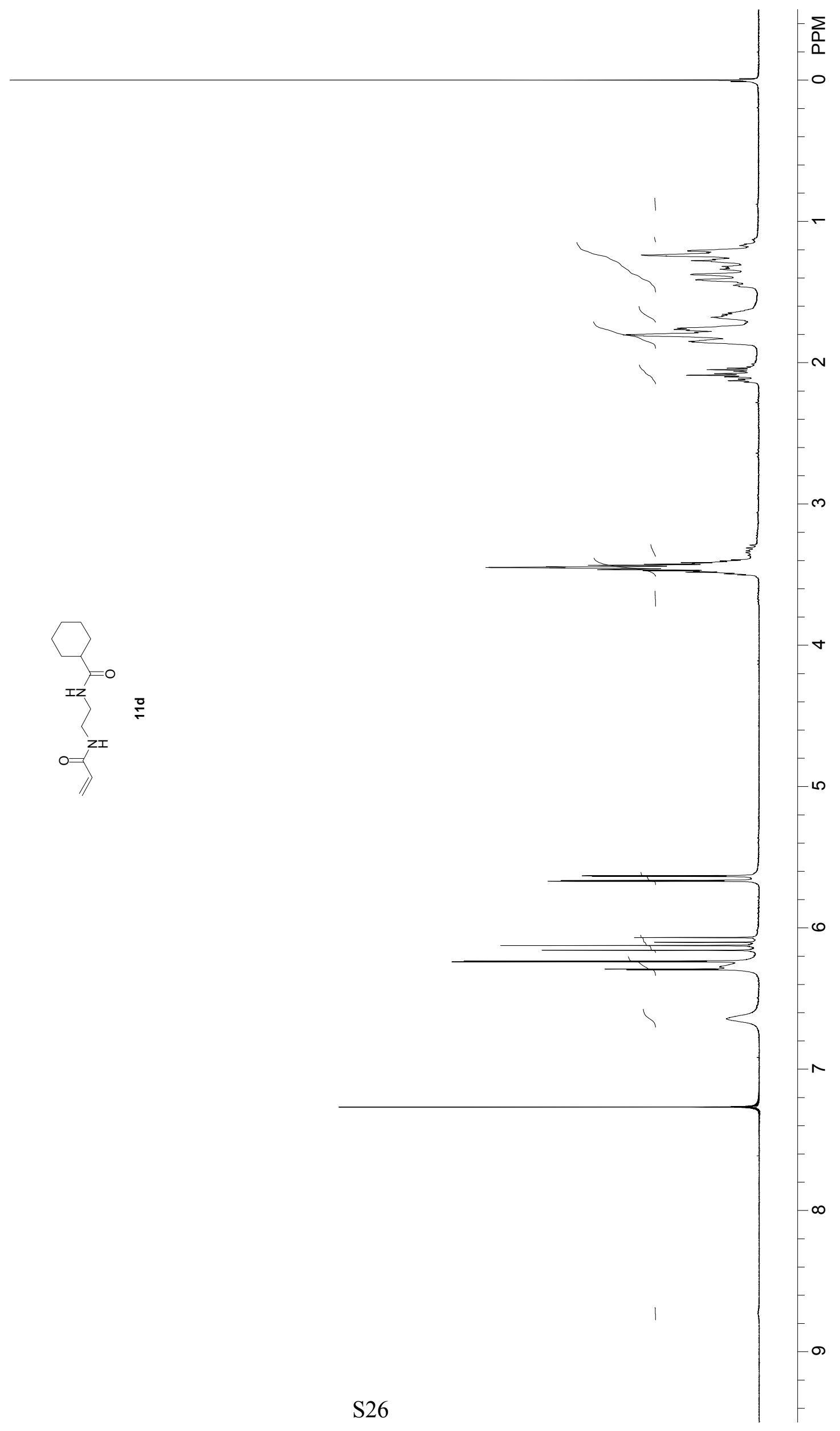




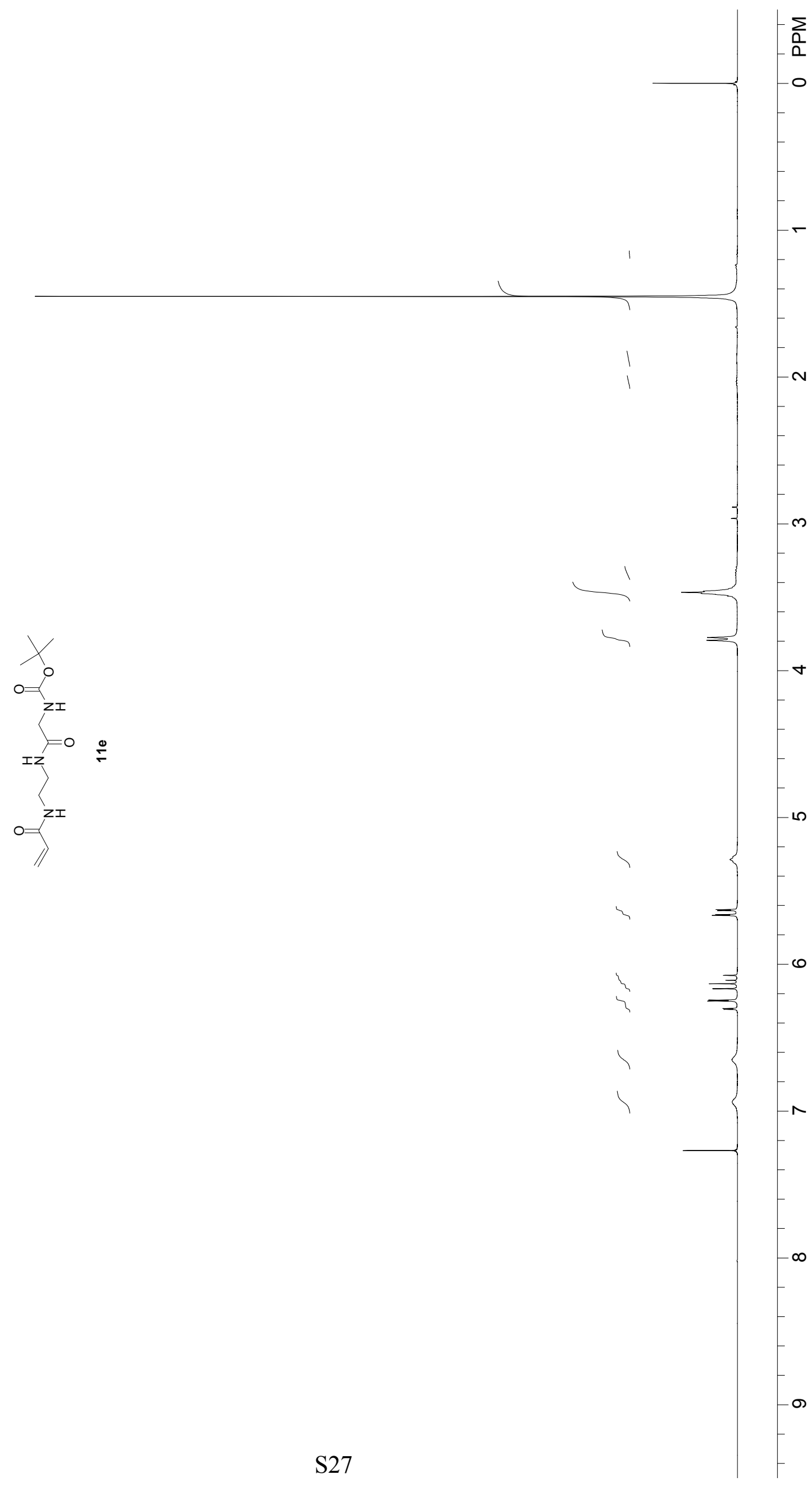




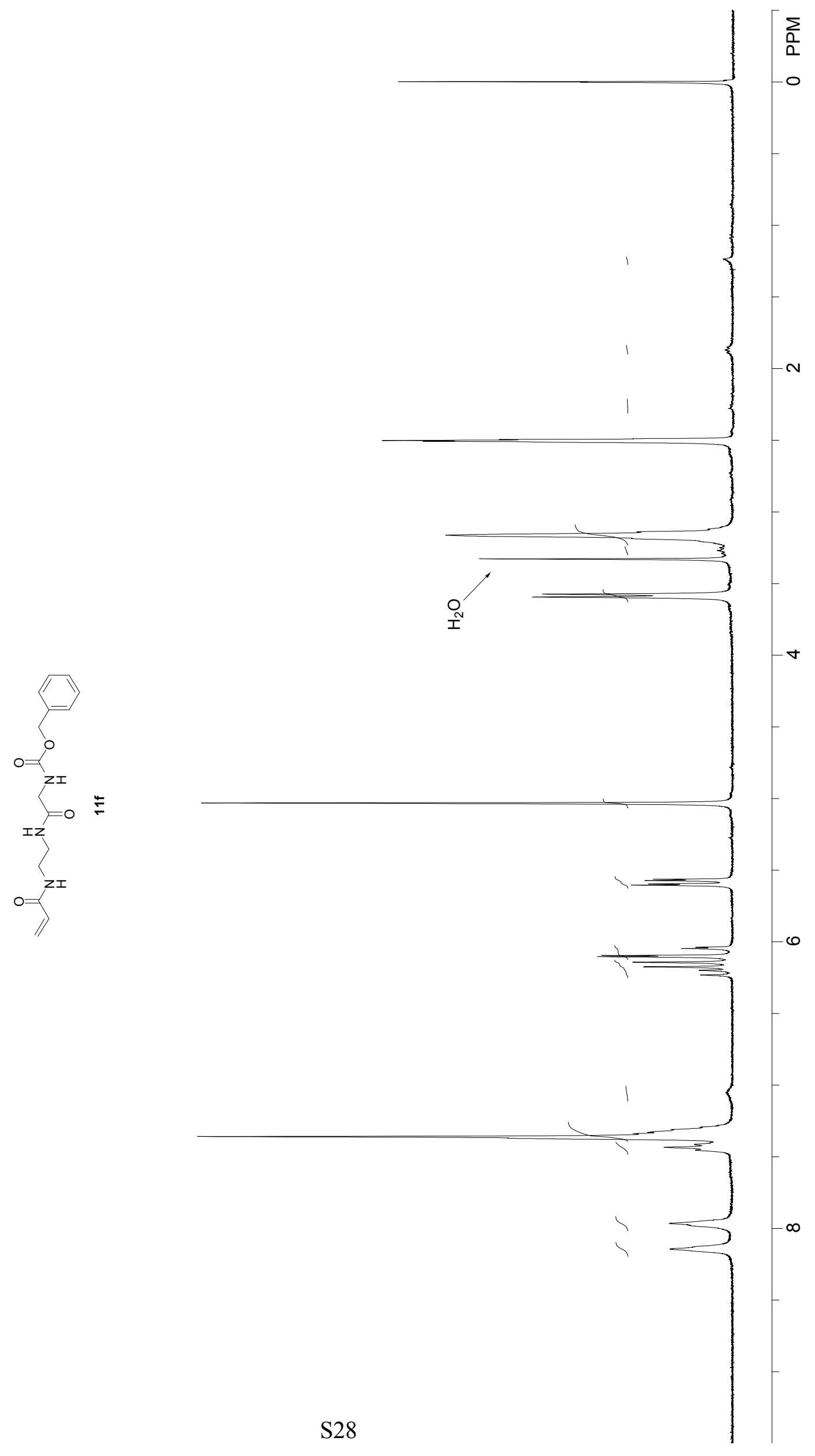




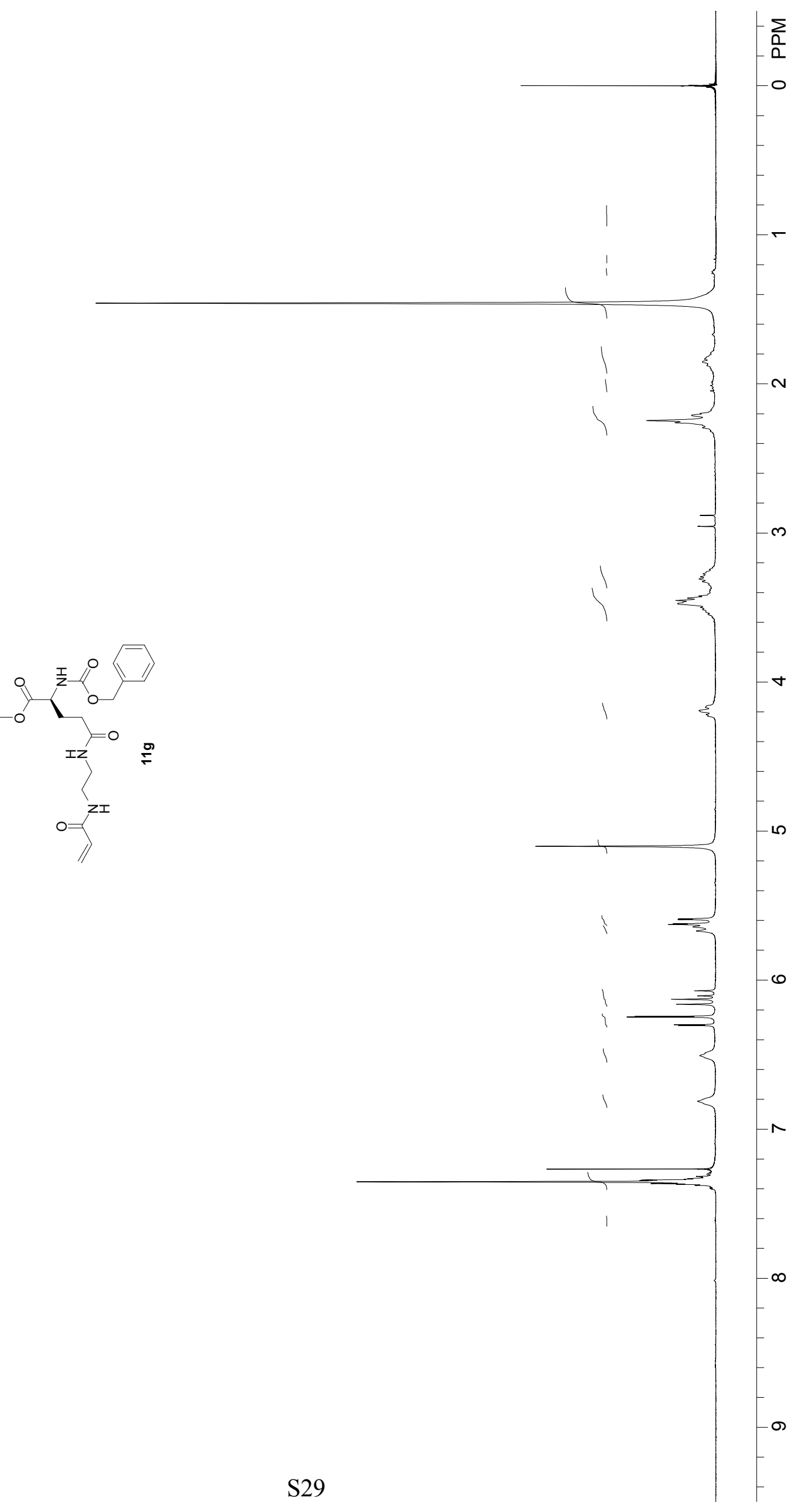




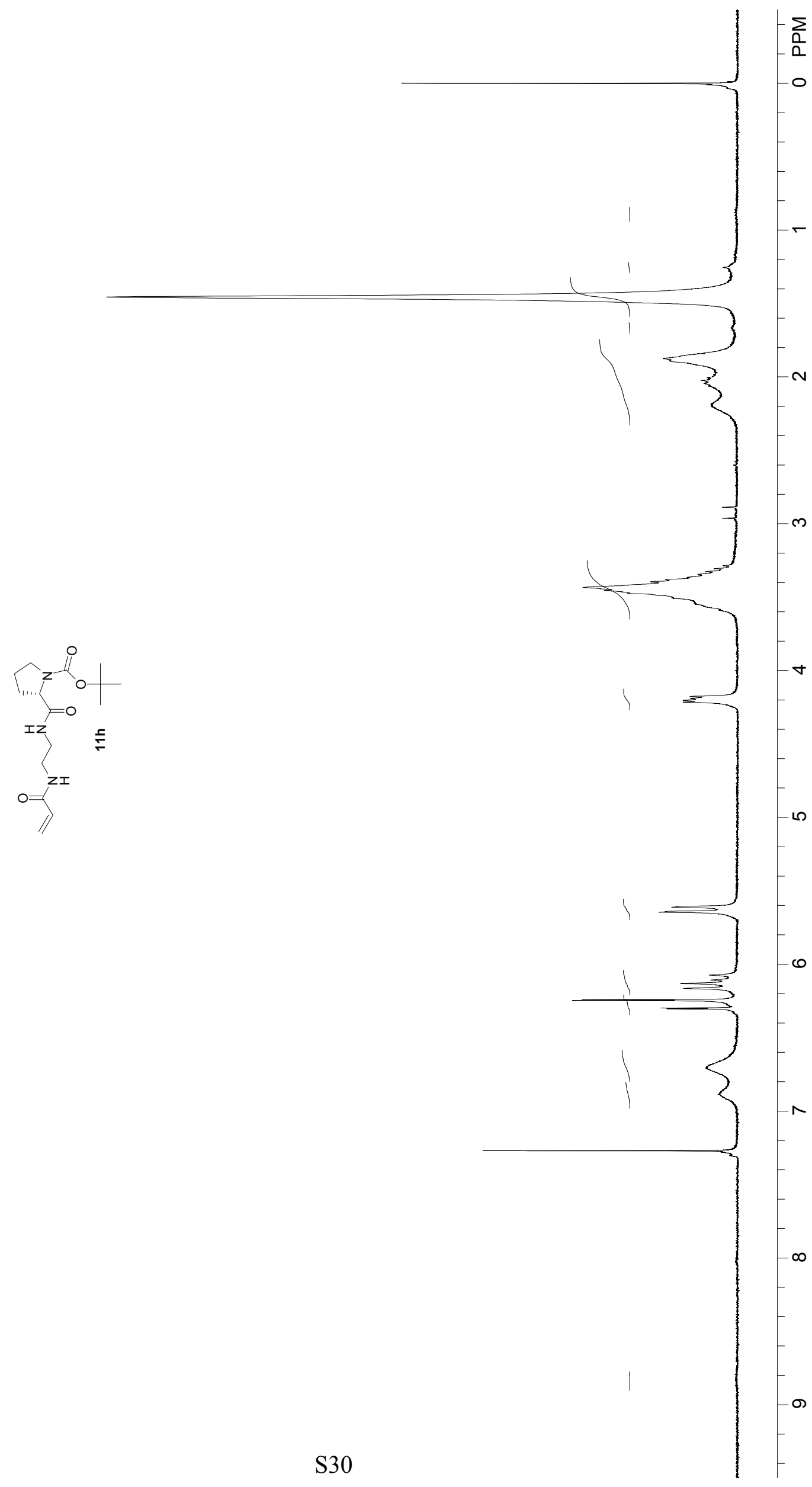




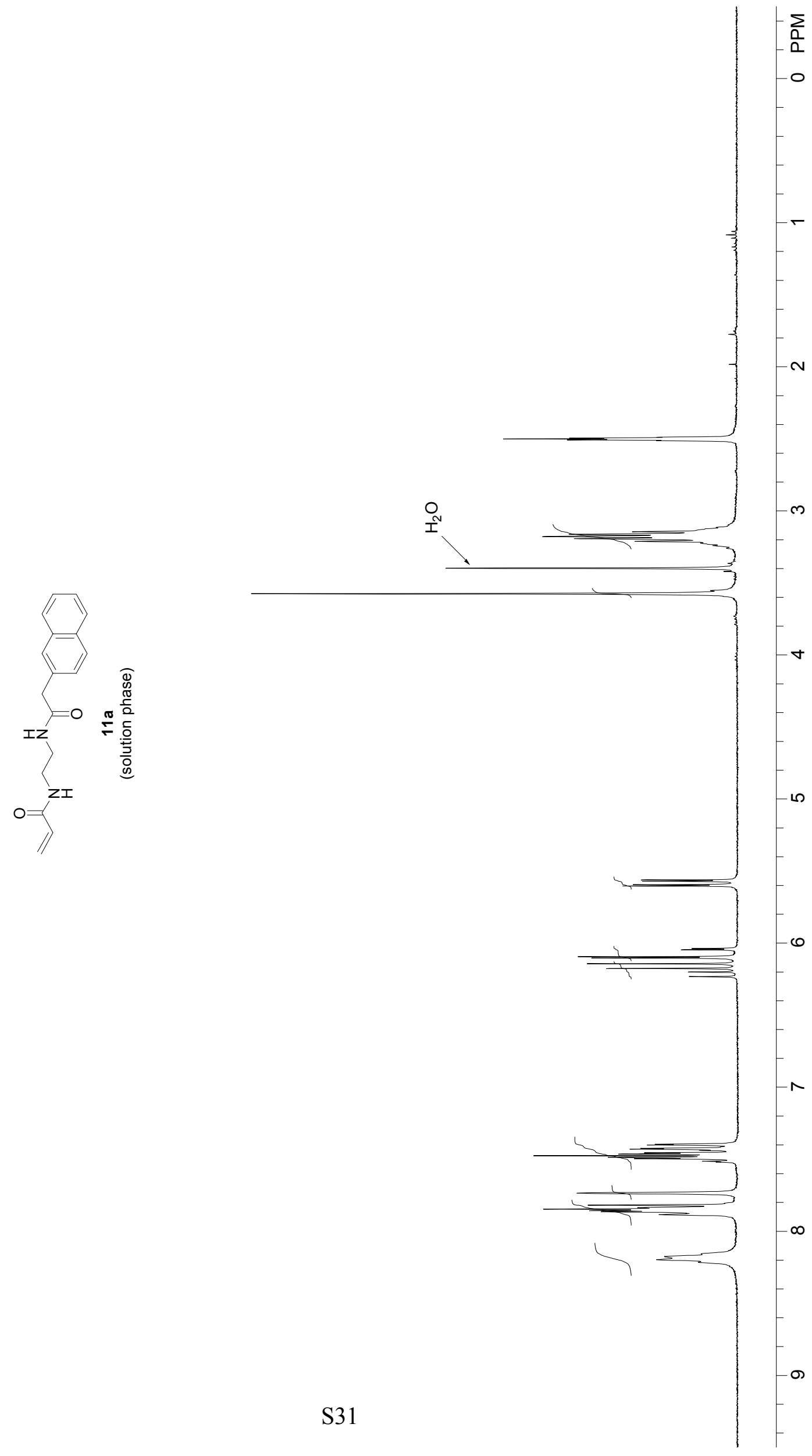




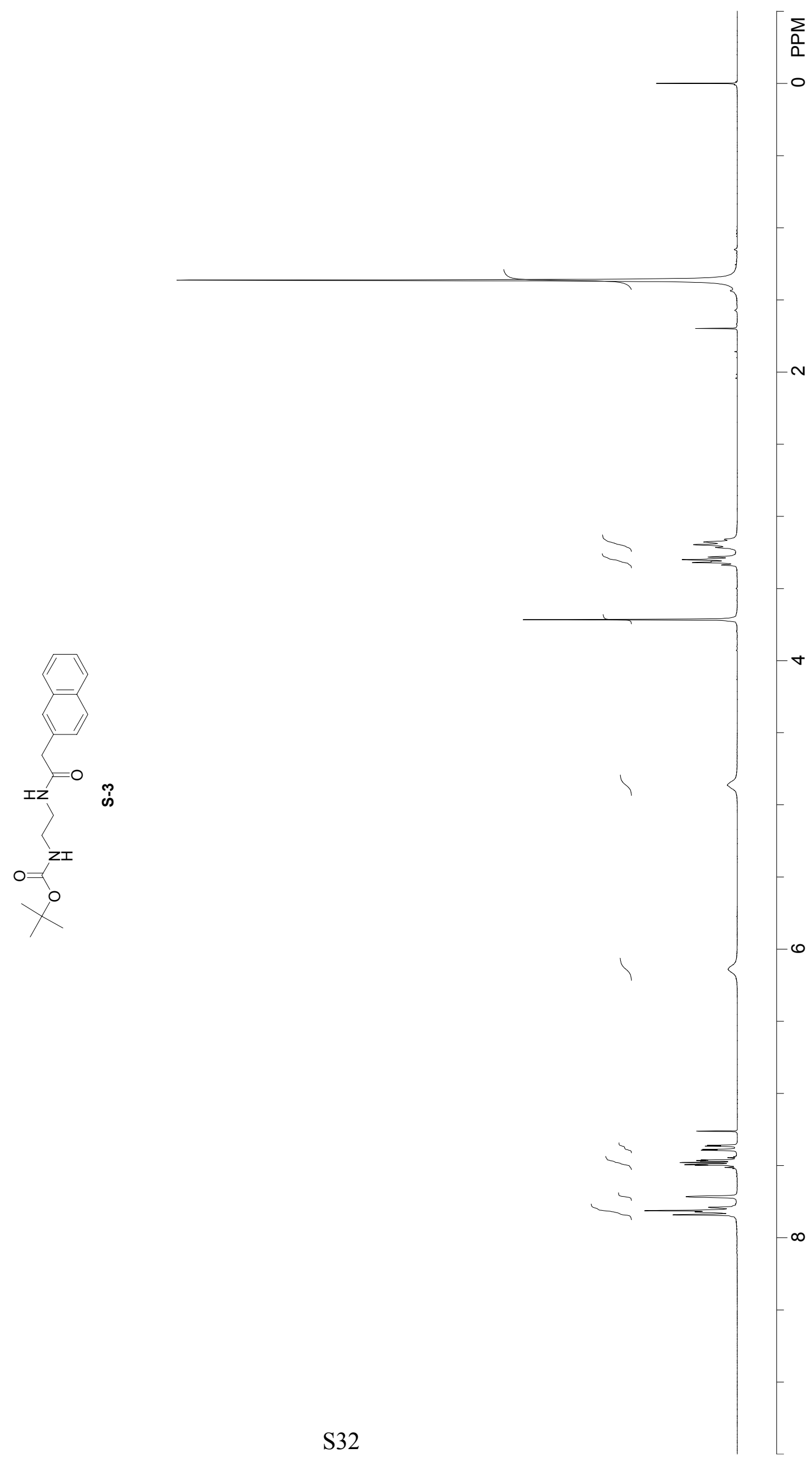




\section{References}

(1) Fel'dman, I. K. Zh. Obshch. Khim. 1962, 32, 1039-1042.

(2) Pons, J.-F.; Fauchere, J.-L.; Lamaty, F.; Molla, A.; Lazaro, R. Eur. J. Org. Chem. 1998, 853-859.

(3) Novabiochem Method 12: Estimation of level of first residue attachment. Catalog and Peptide Synthesis Handbook: San Diego, 1999, p S43. 